\title{
Opportunities for Energy Conservation through Biotechnology
}

J. K. Young

E. A. Griffin

J. A. Russell

November 1984

Prepared for the U.S. Department of Energy under Contract DE-AC06-76RLO 1830

Pacific Northwest Laboratory

Operated for the U.S. Department of Energy by Battelle Memorial Institute 


\title{
DISCLAIMER
}

This report was prepared as an account of work sponsored by an agency of the United States Government. Neither the United States Government nor any agency thereof, nor any of their employees, makes any warranty, express or implied, or assumes any legal liability or responsibility for the accuracy, completeness, or usefulness of any information, apparatus, product, or process disclosed, or represents that its use would not infringe privately owned rights. Reference herein to any specific commercial product, process, or service by trade name, trademark, manufacturer, or otherwise, does not necessarily constitute or imply its endorsement, recommendation, or favoring by the United States Government or any agency thereof. The views and opinions of authors expressed herein do not necessarily state or reflect those of the United States Government or any agency thereof.

\author{
PACIFIC NORTHWEST LABORATORY \\ operated by \\ BATTELLE \\ for the \\ UNITED STATES DEPARTMENT OF ENERGY \\ under Contract DE-AC06-76RLO 1830
}

\begin{tabular}{|c|c|}
\hline \multirow{2}{*}{\multicolumn{2}{|c|}{ Printed in the United States of America }} \\
\hline & \\
\hline \multicolumn{2}{|c|}{ National Technical Information Service } \\
\hline \multicolumn{2}{|c|}{$\begin{array}{l}\text { National Technical Information Service } \\
\text { United States Department of Commerce }\end{array}$} \\
\hline \multirow{2}{*}{\multicolumn{2}{|c|}{$\begin{array}{c}5285 \text { Port Royal Road } \\
\text { Springfield, Virginia } 22161\end{array}$}} \\
\hline & \\
\hline \multirow{2}{*}{\multicolumn{2}{|c|}{$\begin{array}{l}\text { NTIS Price Codes } \\
\text { Microfiche A01 }\end{array}$}} \\
\hline & \\
\hline \multicolumn{2}{|c|}{ Printed Copy } \\
\hline Pages & $\begin{array}{l}\text { Price } \\
\text { Codes }\end{array}$ \\
\hline $001-025$ & $\mathrm{~A} 02$ \\
\hline 026-050 & $\mathrm{A} 03$ \\
\hline 051-075 & AO4 \\
\hline $076-100$ & A05 \\
\hline $101-125$ & A06 \\
\hline $126-150$ & $\mathrm{~A} 07$ \\
\hline $151-175$ & A06 \\
\hline $176-200$ & $\mathrm{~A} 09$ \\
\hline $201-225$ & A010 \\
\hline 226-250 & A011 \\
\hline $251-275$ & A012 \\
\hline 276-300 & A013 \\
\hline
\end{tabular}




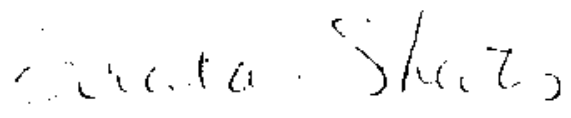

कै Battelle

Pacific Northwest laboratories

P.O. Box 999

Richland, Washington U.S.A. 99352

Telephone (509)

Telex 15-2874 $376-4457$

September 3, 1985

Recipients of PNL-RAP-32 P Nh -5295

Dear Recipients:

RE: Opportunities for Energy Conservation through Blotechnoleax, Pacific Northwest Laboratory, Rich land, Washington, January 1979

Please make the following changes in your copy of the subject report:

PAGE

vil

paragraph 4, 1 in 5; "or about 115 quads" should read "or about 1.15 quads"

3.18

paragraph 1 , 1 line $2 ; 8.9$ quads should be changed to 6.7 quads

3.18

paragraph 1, line 3; reference (U.S. DOE 1983) should read (OTA 1983)

3.19

paragraph 4, line 4; 1-3 butanediol should be changed to n-butano 1

3.20

3.21

3.22

3.24

3.24
Fig 3.2, reference to 2.3 butanediol should say n-butanol

Fig 3.3, reference to 1,3 butanediol should read n-butanol

Table 3.11 , heading of last column; should read $10^{12}$ instead of $10^{15}$

Table 3.12, column 1; reference to 2, 3 butanediol should read n-butanol

Table 3.12, Footnote (b); should read "produced as a byproduct in n-butanol production"

Table 3.12, Footnote $(n)$; should be deleted

Sincerely,

Gran $X$.

Joan K. Young

Research Engineer

Technology Performance Analysis Section

$J K Y: k r p$ 

OPPORTUNITIES FOR ENERGY

CONSERVATION THROUGH BIOTECHNOLOGY
J. K. Young
E. A. Griffin
J. A. Russell

November 1984

Prepared for
the U.S. Department of Energy
Energy Conversion and Utilization
Technologies Division
under Contract OE-ACO6-76RLO 1830

Pacific Northwest Laboratory Richland, Washington 99352 


.




\section{PREFACE}

The Energy Conversion and Utilization Technologies (ECUT) Program of the U.S. Department of Energy supports the long-term, high-risk, generic, applied research and exploratory development necessary to ensure the availability of an advanced technology base that will l) substantially increase the efficiency of energy conversion and utilization systems, and 2) promote the use of noncritical fuels. The ECUT Program seeks to accomplish these goals as follows:

1. conduct applied research and exploratory development activities that address specific problems associated with efficiency limits and multi-fuel use;

2. research and develop processes and materials that improve the efficiency and the alternative fuel use capabilities of energy conversion devices, components, and systems;

3. monitor advances in basic scientific research and evaluate them for applicability to energy conservation;

4. establish the feasibility of innovative revolutionary concepts that significantly reduce energy consumption; and

5. conduct exploratory development of novel and innovative conservation concepts.

Biotechnology shows considerable promise for saving energy and conserving petroleum resources. The United States is at the forefront of the basic science of genetics and molecular biology. However there is the question of whether this scientific base is adequate and whether it can be effectively transiated into energy saving processes. The ECUT Program is therefore evaluating the energy conservation potential for bioprocessing and trying to determine the appropriate federal role in this area.

Two ECUT studies are being conducted to evaluate bioprocessing as a means of saving energy and using alternative fuels. This report describes a study conducted by the ECUT Systems Analys is Project to identify emerging biotechnologies and provide quantitative estimates of energy savings in various end-use sectors including fuels, chemicals, mining, pollution control, food processing, 
and agriculture. This work is also intended to provide background and focus for a second, more extensive ECUT study being conducted by the National Academy of Sciences (NAS). The NAS study concentrates on evaluating the potential of using industrial bioprocessing methods, with emphasis on the production of bulk or commodity chemicals. The processes currently used to produce these high volume products consume large amounts of energy and use critical petroleum feedstocks. Bioprocessing offers the possibility of using less energyintensive processes and alternative feedstocks such as biomass. The NAS study is addressing the following important technical questions:

- What improvements, if any, can be expected in energy conservation due to the emergence of biotechnology?

- How might these improvements manifest themselves?

- Quantitatively, how significant might these be?

- What course of action should be taken to exploit such opportunities?

- How should such an energy conservation-related use of biotechnological developments fit in with some broader biotechnology policy of the U.S.?

- What is the appropriate federal role in developing biotechnology?

David L. Brenchley, Manager

ECUT System Analysis Project 
EXECUTIVE SUMMARY

This study was conducted by the Pacific Northwest Laboratory (PNL) under contract to the Energy Conversion and Utilization Technologies (ECUT) Program of the U.S. Department of Energy (DOE). The purpose is to identify and quantify potential energy savings available through the development and application of biotechnologies. This information is required in support of ECUT research planning efforts as an aid in identifying promising areas needing further consideration and development. It is also intended as background information for a companion ECUT study being conducted by the National Academy of Science to evaluate the use of bioprocessing methods to conserve energy.

Several studies have been conducted recently to assess the status and implications of the development of biotechnology. The Office of Technology Assessment (OTA) considered institutional, economic, and scientific problems and barriers. (a) The National science Foundation sponsored a study to examine regulatory needs for this new and expanding technology. (b) Somewhat in contrast to these studies, this report covers principally the technical issues.

It should be emphasized that the practicality of many developments in biotechnology is not evaluated soleiy on the basis of energy considerations. Bioprocesses must often compete with well-established coal, petroleum, and natural gas technologies. A complete evaluation of the technical, economical, and ecological impacts of the large-scale applications discussed in this report is not possible within the scope of this study. Instead, this report assesses the potential of biotechnology to save energy so that research into all aspects of implementation will be stimulated for those industries with significant energy savings potential.

(a) Uffice of Technology Assessments (OTA). 1984. Commercial Biotechnology An International Analysis. U.S. Government Printing Uffice, Washington, D.C.

(b) Arthur D. Little, Inc, 1984. Study of Federal Biotechnology Policy Issues. BOA NO. PRA-8400692, Mational Science Foundation, Washington, D.C. 
APPROACH

Since this is an initial ECUT assessment of energy conservation opportunities for biotechnology, a broad scope was deemed important. While this survey investigates many different possibilities, they basically occur in two categories: 1) biomass conversion, and 2) genetic engineering of materials. Biomass conversion deals with processes that use renewable feedstocks to replace fossil-based fuels and chemicals. Genetic engineering is the use of biologically-engineered enzymes and organisms to reduce process energy requirements .

The main interest of this work was to establish the feasibility of using biotechnology to save energy. This was accomplished by examining the potential energy consumption of current and emerging biotechnology applications within promising industries and comparing it with the fossil energy consumption of the conventional technologies. Then estimates were pooled for the industry and extrapolated to a nation-wide basis, based on current energy consumption levels. This in turn provided a basis for determining the relative importance of these technologies for saving energy.

Fossil energy savings from biomass conversion and genetic engineering developments were estimated for fuels production, chemical feedstock production, mining, pollution control, agriculture, and the food industry. In many cases, quantitative estimates could not be made due to lack of data, but a discussion of the potential for fossil fuel energy savings was stili included.

Data for calculations were obtained from various literature sources. Most information on biotechnology is widely scattered; in addition, most of the available literature does not emphasize energy consumption. As a result, an extensive literature review was required before appropriate data could be obtained and evaluated. A peer review process was then used to evaluate the data selected for anaiysis. Several reviewers were utilized because of the large number of technologies and industries evaluated in this report. 


\section{FINDINGS}

Estimated energy savings from specific applications of these technologies are discussed on an industry-by-industry basis below. Savings are expressed in quadrillion Btu (quads, equal to $10^{15} \mathrm{Btu}$ ) on an annual basis. Energy savings for biomass conversion processes include the fossil feedstock energy replaced by biomass derivatives.

\section{Fuels}

- Using wastes, residues, and surplus crops currently availabie, about 3.1 quads could be replaced by biomass-derived fuels. This represents up to $1 \%$ of the current liquid fuel consumption and $16 \%$ of the gaseous fuels consumption in the U.S. in 1982.

- Based on PNL calculations, replacing the 26.9 quads of liquid fuels and the 17.9 quads of gaseous fuels used in 1982 with biomass-derived methanol, ethanol, or SNG would require significantly larger quantities of land than are currently available.

\section{Chemicals}

- Using available supplies of biomass, a potential fossil-feedstock energy saving of over 2.1 quads is possible for the synthesis of existing organic chemical feedstocks and nitrogenous fertilizer. However, process energy requirements exceed conventional requirements by $160 \%$, or about 175 quads, due to problems such as diluted products. $\quad 1.15$

- Genetic engineering of biocatalysts and the development of the corresponding scaled-up bioreactions systems could significantly reduce the energy requirements in both the conventional and biomass-based chemicals industry scenarios. However, a biomass-based industry would make use of a renewable feedstock, while the conventional industry uses petroleum feedstock.

\section{Mining}

- Approximately $20 \%$, or 0.014 quads of the energy currently used for metal mining could be saved if bacterially-assisted in-situ recovery methods were utilized. 
- Bioaccumulation techniques for the recovery of gold and silver from waste streams could potentially save the 0.002 quads currently required for mining these precious metals.

Pollution Control

- Utilization of microbial desulfurization of coal, anaerobic digestion of sewage, and deep-shaft aeration of industrial organic waste for poliution control could save at least 0.71 quads or $33 \%$ of the total energy estimated to be currently used for this purpose.

\section{Food Processing}

- Two food processing industries that have a potential for energy savings through biotechnology are fruit processing and meat packing. During the fruit pulping operation, up to $50 \%$ of the energy required, or 0.23 trillion Btu, could be saved by using enzymatic liquefaction methods. Using enzyme-based cleaners, the meat packing industry could save 0.38 trilition Btu.

\section{Agriculture}

- Utilization of genetic engineering to increase the disease- and pestresistance of plants would reduce the consumption of agrichemicais and fuels used to grow crops. A $10 \%$ reduction is estimated, with a calculated savings of about 0.2 quads per year.

CONCLUSIONS AND RECOMMENDATIONS

The quantitative estimates obtained for this study substantiate the premise that biotechnology offers a substantial potential for energy savings. Additional conclusions and the resulting recommendations are described below.

- Genetic engineering and bioprocessing developments provide industry with the potential to save energy and substitute for fossil fuel.

However, substantial technical barriers to implementing these processes in certain industries exist. 
Recommendation:

PNL therefore recommends that the energy savings opportunities described in this report be used as a basis for prioritizing research to eliminate the technical barriers to large-scale applications of biotechnologies.

- Land requirements for biomass growth limit the large-scale replacement of fossil fuels with biomass-derived fuels. Land requirements could be reduced with genetic engineering to improve current yields of biomass and to increase current glucose to cellulose conversion rates.

Genetic engineering of biocatalysts and bioreactors could allow biomass conversion technologies to approach theoretical yields of glucose from cellulose. Current biomass yields could be potentially improved by using genetic engineering developments to increase photosynthetic efficiencies, promote biological nitrogen fixation, improve the water retention of soil, and/or increase disease- and pest-resistance.

\section{Recommendation:}

Therefore, a balanced program to improve biomass yields and conversion technologies should be implemented and supported.

- Chemicals production is potentially a more attractive use of current biomass supplies, since the dollar value added is greater for chemicals than fuels.

The OTA study concluded that commodity chemicals will not be produced by U.S. industry for at least twenty years because of the industry's complex infrastructure, reliance on petroleum feedstocks, and low profit margin. However, the information developed in this project suggests that technical issues, such as high process energy requirements, inhibit chemicals production from biomass. 
Recommendation:

The technology to design stable biocatalysts in immobilized bioreactor systems should be developed. This would provide more effective catalysts for bioprocessing, which would in turn lead to lower process energy requirements. This could be the key step in the development of a competitive biomass-based chemicals industry.

- Genetic engineering advances that affect more energy-intensive sectors of the economy (such as fuels and chemicais) will also affect pollution control, metals mining and recovery, food processing, and agriculture.

Several industrial-specific factors must be considered to effectively exploit the energy saving opportunities provided by genetic engineering R\&D:

a) The implementation of biological methods to reduce energy requirements for pollution control could become more desirable in the future due to stricter regulations; however, the most important consideration for industry will be compliance with standards.

b) Mining of deep deposits is expected to increase, but the geologic and mineralogic limitations that currently inhibit the applicability of bacterially-assisted "in-situ" methods must be addressed.

c) For food processing, particular attention should be paid to enzymatic methods.

d) Many of the genetic engineering opportunities for improved biomass yields also apply to agriculture, but public acceptance may limit their utilization. 


\section{ACKNOWLEDGMENTS}

Because of the broad range of technical issues covered in this report the advice, judgment, and information obtained from several experts in these areas were especially valuable. In particular, the authors extend their appreciation to Dr. William J. Sheppard and Edward S. Lipinsky of Battelle-Columbus Laboratories, and John D. Ingham of the Jet Propulsion Laboratory. In addition, many internal Pacific Northwest Laboratory staff provided valuable technical suggestions, including Dr. Gordon Williams, David E. Eakin, Robert A. Hutchinson, and Daniel R. Johnson.

Editorial patience and assistance was provided by Judy E. Danko and Donna C. Kuick. The managerial guidance of Dr. David L. Brenchley, ECUT Program Manager at PNL, was also greatly appreciated by the authors. 



\section{CONTENTS}

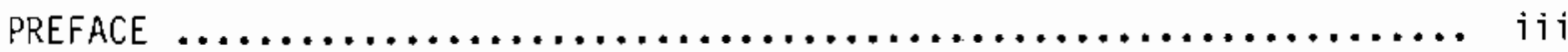

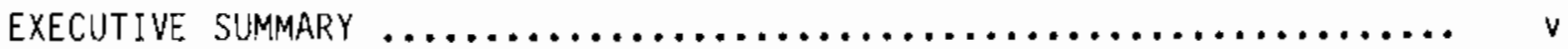

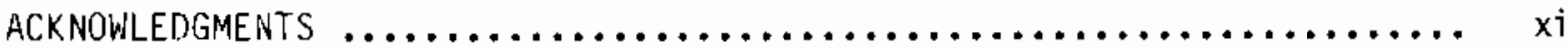

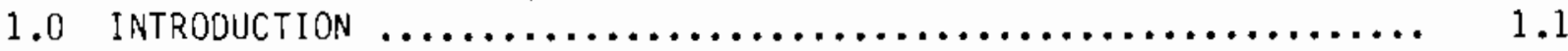

2.0 BIOMASS CONVERSION AND GENETIC ENGINEERING TECHNOLOGIES $\ldots \ldots \ldots .2 .1$

2.1 BIOMASS CONVERSION TECHNOLOGIES $\ldots \ldots \ldots \ldots \ldots \ldots \ldots \ldots \ldots \ldots . . \ldots \ldots$

2.1.1 Current Availability of Biomass $\ldots \ldots \ldots \ldots \ldots \ldots \ldots .2 .1$

2.1 .2 Potential for Future Production $\ldots \ldots \ldots \ldots \ldots \ldots \ldots .2 .2$

2.2 TECHNOLOGIES FROM GENETIC ENGINEERING $\ldots \ldots \ldots \ldots \ldots \ldots \ldots \ldots$

3.0 BIOMASS CONVERSION APPLICATIONS $\ldots \ldots \ldots \ldots \ldots \ldots \ldots \ldots \ldots \ldots \ldots \ldots \ldots \ldots \ldots$

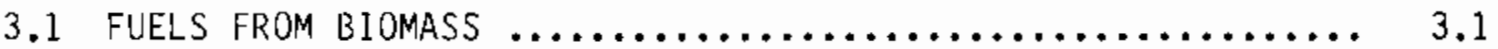

3.1 .1 Determination of Energy-Efficient Methods
for Producing Fuels from Biomass $\ldots \ldots \ldots \ldots \ldots \ldots \ldots . . . \ldots$

$\begin{aligned} & 3.1 .2 \text { Current Potential Energy Savings from } \\ & \text { Bio-derived Fuels } \ldots \ldots \ldots \ldots \ldots \ldots \ldots \ldots \ldots \ldots \ldots \ldots \ldots \\ &\end{aligned}$

3.1.3 Research Needs for Fuels Production ............ 3.16

3.2 BIOMASS AS A CHEMicAl fEEdSTOCK $\ldots \ldots \ldots \ldots \ldots \ldots \ldots \ldots \ldots \ldots . . \ldots \ldots$

3.2.1 Structure of Biomass-Based Chemicals Industry ...... 3.19

3.2.2 Comparison of Energy Consumption for Chemicals $\ldots . .3 .22$

3.2.3 Research Needs for Biomass as a

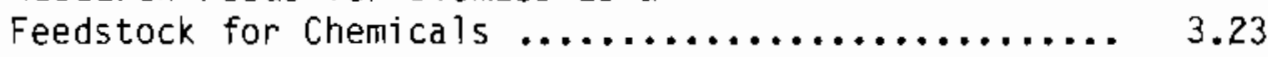

4.0 APPLICATIONS FROM GENETIC ENGINEERING $\ldots \ldots \ldots \ldots \ldots \ldots \ldots \ldots \ldots \ldots . \ldots \ldots$

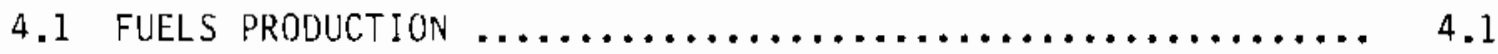

4.1.1 Current Limitations to Large-Scale

Fuels Substitution ...................... 4.1

4.1.2 Potential Impact of Genetic Engineering .......... 4.2 
4.2 CMEMICALS PRODUCTION $\ldots \ldots \ldots \ldots \ldots \ldots \ldots \ldots \ldots \ldots \ldots \ldots, \quad 4.6$

4.2.1 Advantages of Bioprocessing $\ldots \ldots \ldots \ldots \ldots \ldots \ldots \ldots, 4.7$

4.2.2 Limitations to Implementation of Bioprocesses ...... 4.8

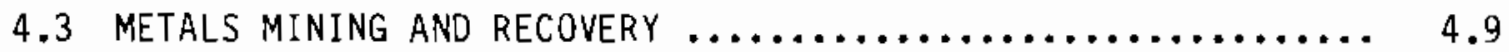

4.3.1 Bacterially-Assisted Recovery Methods ............ 4.9

4.3.2 Energy Savings from Biotechnology .............. 4.12

4.3.3 Research Needs for Metals Mining and Recovery ...... 4.13

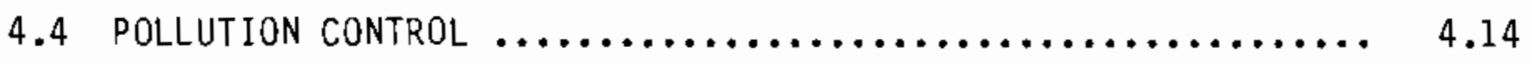

4.4 .1 Possibilities for Biotechnological
Pollution Cont rol $\ldots \ldots \ldots \ldots \ldots \ldots \ldots \ldots \ldots \ldots \ldots \ldots \ldots \ldots \ldots \ldots$

4.4.2 Energy Savings Impact of
Available Biotechnology $\ldots \ldots \ldots \ldots \ldots \ldots \ldots \ldots \ldots \ldots, 4.18$

4.4.3 Future Developments In Pollution Control .......... 4.20

4.5 FOOD INDUSTRY $\ldots \ldots \ldots \ldots \ldots \ldots \ldots \ldots \ldots \ldots \ldots \ldots \ldots \ldots \ldots, 4.22$

4.5.1 Potential Biotechnological Developments ........... 4.23

4.5.2 Potential Energy Savings from Biotechnology ........ 4.24

4.5.3 Research Needs for Foods Production .............. 4.25

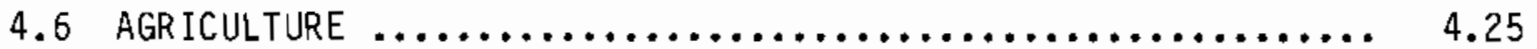

4.6.1 Energy Use for Conventional Methods ............. 4.26

4.6.2 Energy Savings Potential of Biotechnology ......... 4.27

5.0 SUMMARY OF ENERGY SAVINGS FROM BIDTECHNOLOGY $\ldots \ldots \ldots \ldots \ldots \ldots \ldots .5 .1$

5.1 BIOMASS CONVERSION TECHNOLOGIES $\ldots \ldots \ldots \ldots \ldots \ldots \ldots \ldots \ldots, 5.1$

5.1 .1 Fuels Production $\ldots \ldots \ldots \ldots \ldots \ldots \ldots \ldots \ldots \ldots \ldots, 5.1$

5.1 .2 Chemicals Production $\ldots \ldots \ldots \ldots \ldots \ldots \ldots \ldots \ldots \ldots, 5.1$

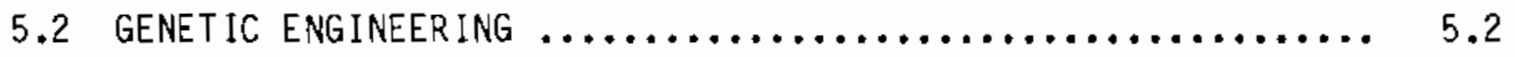

5.2 .1 Fuels Production $\ldots \ldots \ldots \ldots \ldots \ldots \ldots \ldots \ldots \ldots \ldots . \ldots . . .2$

5.2 .2 Chemicals Production $\ldots \ldots \ldots \ldots \ldots \ldots \ldots \ldots \ldots \ldots . .6 .2$ 
5.2 .3 Metals Mining and Recovery ................. 5.3

5.2 .4 Pollution Control ....................... 5.3

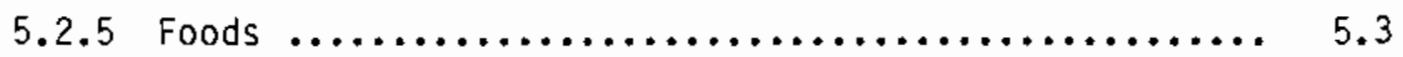

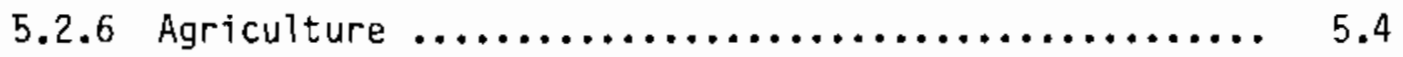

REFERENCES $\ldots \ldots \ldots \ldots \ldots \ldots \ldots \ldots \ldots \ldots \ldots \ldots \ldots \ldots \ldots \ldots \ldots \ldots \ldots \ldots \ldots \ldots \ldots$

APPENDIX A - PROCESS DETAILS OF LIQUID AND GASEOUS FUELS PRODUCTION ..................................... A.

APPENDIX B - BIOMASS PRODUCTION REQUIREMENTS FOR LIQUID

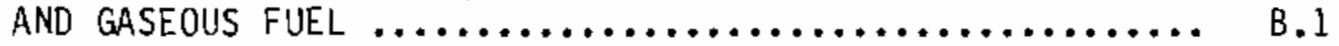


FIGURES

3.1 Structure of Organic Chemicals Industry $\ldots \ldots \ldots \ldots \ldots \ldots \ldots \ldots \ldots . . \ldots \ldots$

3.2 Biomass-Based 0rganic Chemicais Industry $\ldots \ldots \ldots \ldots \ldots \ldots \ldots \ldots \ldots$

3.3 Synthesis Routes to Major Chemical Intermediates ............ 3.21

4.1 Potential Availability of Biomass to

Provide Liquid Fuel from Methanol ...................... 4.3

4.2 Potential Availability of Biomass to

Provide Liquid Fuel from Ethanol ...................... 4.4

4.3 Potential Availability of Biomass to

Provide Gaseous Fuel from $S N G$......................... 4.5 
$\underline{\text { TABLES }}$

3.1 Quantity and Types of Energy Consumed in 1982, by Sector ...... 3.2

3.2 Estimated 1982 Energy Use By Type and by Industry in Quads ..... 3.3

3.3 Total Quantities of Liquid or Gaseous Fuels Consumed in $1982 \ldots . .3 .4$

3.4 Process Energy Balances for Ethanol Production from

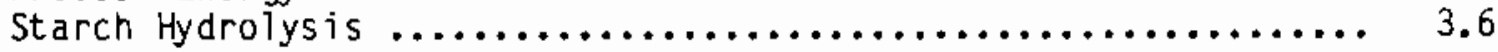

3.5 Process Energy Balance for Ethanol from Cellulose ........... 3.8

3.6 Process Energy Analysis for Methanol from Wood Residue ........ 3.9

3.7 Energy Balance for Wood Gasification $\ldots \ldots \ldots \ldots \ldots \ldots \ldots \ldots \ldots \ldots . . \ldots$

3.8 Available Biomass Sources and Energy Values, 1980 ........... 3.12

3.9 Amount of Fuel that Could be Produced from Biomass .......... 3.13

3.10 Energy Consumption Pattern for the Chemicals Industry ........ 3.18

3.11 Energy Consumption of Primary Chemicals in Conventional

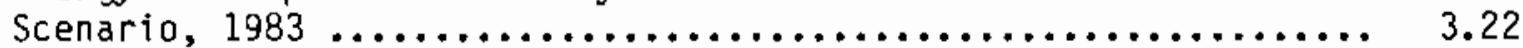

3.12 Energy Consumption for Biologicaliy-Based Chemicals ......... 3.24

4.1 Land Requirements for Biomass Production to Meet
the 1982 Fuel Demand $\ldots \ldots \ldots \ldots \ldots \ldots \ldots \ldots \ldots \ldots \ldots \ldots \ldots \ldots \ldots \ldots \ldots \ldots \ldots$

4.2 Process Energy Required per Ton Product .................. 4.10

4.3 Energy Consumption in Metal Production (10 12 Btu), $1980 \ldots \ldots . . .4 .11$

4.4 Pollution Control Energy by Consumer and by Pollutant Type ..... 4.15

4.5 Energy Requirements for Four Biodegradation Techniques ....... 4.18

4.6 Energy Balance for Anaerobic Digestion of Sewage Sludge ....... 4.19

4.7 Potential Energy Savings for Microbial Desulfurization ........ 4.19

4.8 Series of Calculations to Determine Potential Energy Savings for Deep-Shaft Aeration of Organic Wastes ................ 4.21

4.9 Top Five Food Industry Energy Consuming Groups in $1980 \ldots \ldots \ldots \ldots$... 4.22

4.10 Energy Use in Farm Production 1974-1990 ................. 4.25 
4.11 Analysis of Spirulina Algae and Other Protein Sources.......... 4.29

5.1 Total Energy Savings Estimate for

Biological Pollution Control, $1982 \ldots \ldots \ldots \ldots \ldots \ldots \ldots \ldots \ldots \ldots \ldots . \ldots \ldots$ 


\subsection{INTRODUCTION}

This report establishes the feasibility of using biotechnology to reduce domestic reliance on fossil fuels. Biotechnology is defined in this study as the use of biological materials to meet the technological needs of mankind. Biotechnological developments include new and improved biomass conversion methods and technologies resulting from the genetic engineering of cells. In biomass conversion processes, energy and materials are obtained from available renewable feedstocks such as wood, grain, and fiber (biomass) using chemical, enzymatic, or thermal methods. Developments from genetic engineering include plants, microorganisms, or enzymes that can be used to produce valuable products or degrade host substances.

Major areas that are expected to be affected by future developments in biotechnology include fuels, chemicals, mining, pollution control, food processing, and agriculture. Major biotechnological applications for these industries are summarized as follows:

- Fuels - synthetic natural gas, ethanol, methanol, and other liquid fuels obtained from renewable resources

- Chemicals - organic chemicals and polymers and nitrogenous fertilizers produced from biofeedstocks and biosynthesis

- Mining - bacterial leaching and biotransformations used to concentrate metals

- Pollution control - degradation of pollutants and conversion of waste products using biotechnological methods

- Foods - processing improvements using biotechnological methods

- Agriculture - use of genetic engineering to produce more vigorous plants, improve nitrogen fixation, and develop algal protein for food.

Biotechnological processes can improve energy efficiency in two ways:

- by utilizing biomass conversion technologies to manufacture renewable feedstocks and fuels to replace fossil-based derivatives, 
- by developing biologically-engineered enzymes and organisms that reduce process energy requirements.

Energy-saving biotechnologies are identified to provide a framework for evaluating the relative merit of various R\&D strategies. Only those biotechnologies with significant energy-savings potential are reviewed. When possible, energy consumption is determined for both the conventional and the biologicallyassisted scenarios so that the energy-savings potential can be quantitatively estimated.

It should be emphasized that the practicality of many developments in biotechnology is not evaluated solely on the basis of energy considerations. Bioprocesses must often compete with well-established coal, petroleum, and natural gas technologies. A complete evaluation of the technical, economical, and ecological impacts of the large-scale applications discussed in this report is not possible within the scope of this study. Instead, this report assesses the potential of biotechnology to save energy so that research into all aspects of implementation will be stimulated for those industries with significant energy savings potential.

The types of biotechnological developments with the potential for energy conservation are described in Section 2.0. These include biomass conversion technologies and technologies from genetic engineering. Section 3.0 discusses the two major applications of biomass conversion technologies--fuels production and chemicals from biomass feedstocks. Section 4.0 discusses the applications of genetic engineering developments for fuels, chemicals, metal mining, pollution control, food processing, and agriculture. The same format is used to discuss each application for both Sections 3.0 and 4.0. First, the current energy consumption for conventional methods is determined for each application and compared with the energy used by the biotechnological methods. Then, the energy savings from biotechnology is estimated. If the potential iarge-scale energy savings are not currently feasible due to technical barriers, research needs are identified. The results of each section are summarized in Section 5.0 . 


\subsection{BIOMASS CONVERSION AND GENETIC ENGINEERING TECHNOLOGIES}

The two biological materials with the greatest potential for energy conservation are biomass and genetically-engineered microorganisms. Improved biomass conversion technologies and advanced techniques for the genetic manipulation of microorganisms will provide industry with potentially viable alternatives to conventional production methods. The potential for these technologies to save energy will be a key determinant in their implementation.

\subsection{BIOMASS CONVERSION TECHNOLOGIES}

Although biomass can be burned directly to provide process and space heat or steam, it can also serve as the raw material for synthesizing organic fuels and chemicals. As discussed below, large-scale implementation of biomass conversion technologies is currently limited by biomass feedstock supply. However, with proper agricultural management and improvements to photosynthetic efficiencies, biomass can ensure a continuous renewable supply of essential raw materials in the future.

\subsubsection{Current Availability of Biomass}

Total annual biomass production on timberland or cropland in the United States is about 3.5 billion tons/year, not including unproductive or reserved forestland, pasture and rangeland, swampland, or industrial and urban areas. At $8000 \mathrm{Btu} / 1 \mathrm{~b}$, this is about 56 quads of thermal energy (one quad is equal to $10^{15}$ Btu) or $75 \%$ of current domestic energy use. The most that can be reasonably expected to be used is about 1.4 billion tons/year of wood and wood wastes and 550 million tons/year of agricultural residues. The inclusion of an estimated 160 million tons/year of municipal solid wastes and $6.2 \mathrm{million}$ tons per year of surplus crops brings the maximum amount of biomass available to 2.1 billion tons. Only $20 \%$ of this is estimated to be economically available, which reduces the amount of biomass available for energy production to $420 \mathrm{mil}$ lion tons/year or about 7.0 quads/year of thermal energy. If al1 7.0 quads of biomass are processed into fuels and chemicals, only $30 \%$ of the original heat content, or 2.1 quads/year, is available, due to conversion losses (Goldstein 1981). 
About 2.8 quads of the current supply of biomass were consumed for energy in 1982. Of that amount, 0.02 quads were converted to alcohol fuel or methane and the remainder was burned directly (Haggin and Krieger 1983). The DOE and other sources project that about 5 quads/year of biomass will be available by the year 2000 (Klass 1983, Science 1979).

\subsubsection{Potential for Future Production}

The development of plants with photosynthetic efficiencies much greater than the current values of under $1 \%$ would vastly increase the production of biomass. The theoretical maximum photosynthetic yield of plants has been estimated at around 100 tons/acre-year (Bassham 1977), but many experts feel that even 50 tons/acre-year is optimistic. At about $5000 \mathrm{Btu} / \mathrm{lb}$ and 50 tons/acreyear, the 482 million acres of land avallable for intensive agriculture in the year 2000 could produce 240 quads/year by burning biomass directly (two to three times the estimated energy consumption for the year 2000) (Shen and Turnhollow 1983).

Assuming current thermodynamic efficiencies, conversion of biomass to liquid or gaseous fuels significantly decreases the amount of energy originally available in the biomass resource. At least one-half to two-thirds of the energy content of the biomass is lost during the conversion process. However, conversion of the maximum amount of biomass potentially available from agricultural iand in the year 2000 would result in at least 80 quads of liquid or gaseous fuel. This is about $80 \%$ of the projected demand for primary energy in the year 2000 .

Ecological impacts and imbalances of large-scale biomass production must aiso be considered. For example, a biomass energy plantation would be vulnerable to crop failures and fire. Sustained agricultural production also causes depletion of soil nutrients and excessive topsoil erosion. In addition, biomass not only competes with the production of food, but with many other materials. An integrated energy plantation providing food and materials, in addition to energy feedstock, would be a possible alternative. Considerable $R \& D$ and drastic changes in the nation's eating habits would probably be required to realize the advantages of large-scale fuel production from 
biomass. Despite these facts, many argue that biomass fuels are desirable because they can be sustained indefinitely and they employ unskilled workers.

\subsection{TECHNOLOGIES FROM GENETIC ENGINEERING}

Genetic engineering involves manipulating the genetic material (DNA) of a living cell so that the cell can produce valuable metabolites or perform completely new or enhanced functions.

Genetic alterations can be induced by either recombinant DNA or nonrecombinant DNA methods. In recombinant DNA methods, genes from separate sources are isolated and then spliced together chemically into a functional unit. Nonrecombinant techniques used by genetic engineers in conjunction with genesplicing technologies include:

- Induced mutations - a chemical or physical agent is used to interfere with normal cellular processes.

- Cell fusion - two cell types are fused together into a single unit. Monoclonal antibodies and tissue culturing (protoplast fusions) are two cell fusion approaches.

- Conjugation (plasmids) - a one-way transfer of DNA between bacteria during cellular contact.

- Transduction - DNA is transferred between bacteria using a transmitting agent such as a virus.

Genetic engineering will result in a variety of microbes and plants with traits that can be used to conserve energy. Some of the practical applications of genetically-engineered microorganisms are as follows:

- microbial production of fuels and chemicals from biomass

- manufacture of enzymes to catalyze chemical reactions

- bacterially-assisted leaching or accumulation of metals

- microbial degradation of pollutants

- production of enzymes for food processing

Genetic engineering of plants can also enhance normal cellular functions such as photosynthesis, resulting in more vigorous plants and higher crop productions. 
Currently, the implementation of genetically-engineered materials is limited not only by technical and economic constraints, but also by public acceptance. For example, a bacterium was recently developed that increased the frost-resistance of plants. The bacterium has not been tested under actual field conditions because of public resistance to its release into the environment. 


\subsection{BIOMASS CONVERSION APPLICATIONS}

The following sections discuss the energy-savings impact of biomass conversion technologies on the production of fuels and the use of biomass as a chemical feedstock. Fuels production from biomass is discussed in the beginning sections. The fermentation processes for ethanol production and the gasification processes for methanol and synthesis gas are included.

First, existing processes for producing ethanol from biomass are evaluated to determine the process with the most efficient net energy balance. The processes to produce methanol and SNG by gasification of wood are also presented. Then the scenario in which currently available supplies of biomass are used to replace fossil fuels is discussed. Research needs for fuels production using biomass conversion are identified as a result of this discussion.

The last section discusses the use of biomass as a feedstock for organic chemicals and for manufacturing nitrogenous fertilizers. First, the structure of the bulk chemicals industry is presented along with the necessary modification of that structure to incorporate large-scale production of chemicals from biomass feedstocks. Second, the current consumption of fossil energy by the conventional chemicals industry is compared with a biomass-based industry. Third, the energy-savings impact of using biomass-derived chemical feedstocks is evaluated. Finally, research needs are identified that will improve the technical feasibility of a biomass-based chemicals industry.

\subsection{FUELS FROM BIOMASS}

In 1982, the U.S. consumed a total of $72 \times 10^{15}$ Btu, or 72 quads, of primary energy. About 7 quads of this total energy were consumed by industry, 26 quads by commercial and residential heating, and 19 quads by all forms of transportation. The types of energy consumed by each major user are listed in Table 3.1.

As shown, the transportation sector uses petroleum products almost exclusively (primarily in the forms of gasoline and diesel fuels), while electricity is the largest source of energy for commercial and residential purposes. The industrial sector consumes fossil energy for use as chemical feedstocks as well 
TABLE 3.1. Quantity and Types of Energy Consumed in 1982, by Sector
(in Quads)

$\frac{\text { Sector }}{\text { Industry }(e)} \frac{\text { Coal }}{2.60} \frac{\begin{array}{c}\text { Natural } \\ \text { Gas }\end{array}}{6.91} \frac{\text { Petroleum }}{7.85} \frac{\text { Electricity }(b, c, d)}{8.66} \frac{\text { Other }}{1.17} \frac{\text { Total }}{27.19}$

Commercial

and

\begin{tabular}{|c|c|c|c|c|c|c|}
\hline Residential & 0.21 & 7.50 & 2.49 & 15.50 & 0 & 25.70 \\
\hline Transportation & - & $\underline{0.61}$ & 18.42 & $\underline{0.13}$ & $\underline{0}$ & 19.16 \\
\hline Total & 2.81 & 15.02 & 28.76 & 24.29 & 1.17 & 72.05 \\
\hline
\end{tabular}

(a) Source: DOE (1983)

(b) $10,400 \mathrm{Btu} / \mathrm{kwh}$.

(c) $55 \%$ generated from coal, $14 \%$ from natural gas, $6 \%$ from petroleum, $12 \%$ from nuclear, and 14\% from hydro and biomass as indicated in source cited in footnote (a).

(d) Inciudes electrical losses from transmission and generation as well as electricity actually consumed.

(e) $82 \%$ of energy used for fuel, $18 \%$ for feedstock.

as for fuel. It has been estimated that $82 \%$, or $2: .34$ quads, of the total energy consumption in 1982 for all industries was for fuel and $18 \%$, or 4.85 quads, was for feedstock (Holtberg, et al. 1983). An approximate breakdown for the type of energy consumed by industry is shown in Table 3.2. The fuel total includes electrical energy.

Approximately 44.8 quads of energy consumed in 1982 were in a liquid or gaseous form, as shown in Table 3.3. This includes the petroleum and natural gas used to generate electricity, but excludes the natural gas and petroleum used as feedstock by the industrial sector. Approximately 26.9 quads were consumed as liquid fuel and 17.9 quads as gaseous fuel.

$8 i$ mass-based fuels are evaluated in this report as substitutes for currently used liquid and gaseous fuels. In this assessment, ethanol is produced by fermentation of grain or cellulose, and methanol is manufactured from biomass gasification to replace currently used liquid fuels. Low-to-medium Btu gas from anaerobic digestion or gasification replaces natural gas. 
TABLE 3.2. Estimated 1982 Energy Use by Type and by Industry in Quads(a)

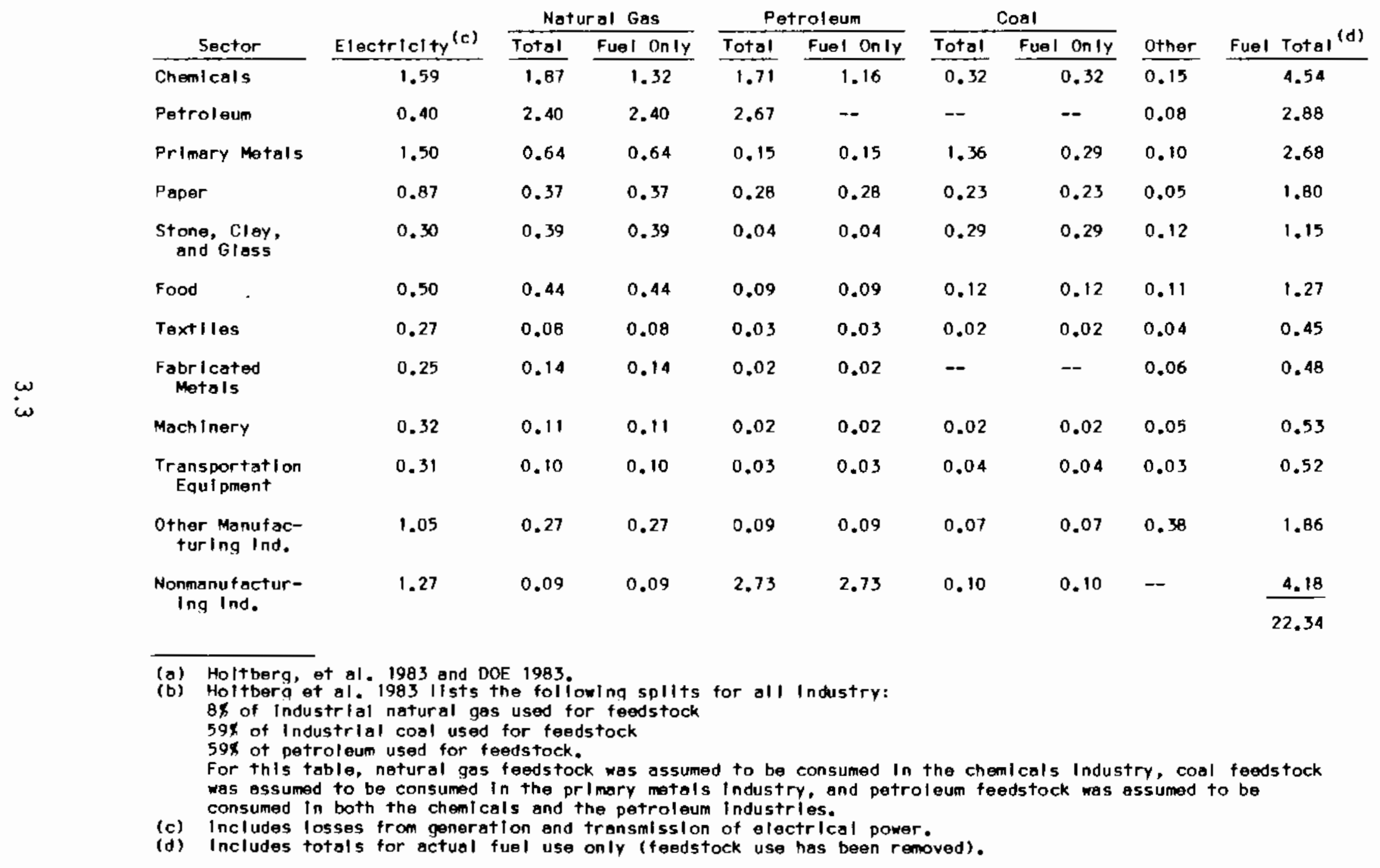


TABLE 3.3. Total quantities of Liquid or Gaseous

Fuels Consumed in 1982

\begin{tabular}{|c|c|c|}
\hline Sector & Liquid (quads) & Gas (guads) \\
\hline Residential and Commercial & 3.4 & 9.7 \\
\hline Industry & 5.1 & 7.6 \\
\hline Transportation & 18.4 & 0.6 \\
\hline Total & 26.9 & 17.9 \\
\hline
\end{tabular}

\subsubsection{Determination of Energy-Efficient Methods for Producing}

Fuels from Biomass

These first sections address the question of whether the production of fueis from various processes requires more energy than is present in the product.

Methods for fuel production that consume more energy for processing than the products contain are defined in this study to have a net energy loss; those methods that require less energy for processing than the products contain are defined to have a net energy gain. In some of the processes evaluated, feedstock or byproducts are used to supply part of the process energy as well as the energy for conversion to separate products. For these cases, the amount of feedstock energy not converted to products was calculated and included in the processing energy.

The processes for ethanol production evaluated include ethanol from hydrolysis of starch and ethanol from hydrolysis of cellulosic wastes. Calculating net energy gain to determine the relative process energy-efficiency of ethanol production is possible, because the conversion ratio of feedstock energy to ethanol output should be nearly the same for the fermentation process studied. There are several limitations to a net energy analysis, however. Net energy calculations cannot be used to compare processes with different feedstock conversion efficiencies; a total energy balarce must be used. In addition, a net energy loss should not be a basis for disregarding biomass-derived fuels, since it does not focus attention on the major advantage of biomass fuels: biomass conversion processes transform renewable feedstocks into desirable substitutes for fossil fuels. 
Other processes discussed include methanol and SNG production from wood gasification. Energy balances for thermochemical conversion of biomass to liquid fuels were not available so it is discussed qualitatively. Production of methane from anaerobic digestion is discussed in the section on pollution control. Details for each of these processes are provided in Appendix A.

Ethanol Production from Starch Hydroiysis

When ethanol is produced from a source of starch such as grain, the materials equation looks something like this (David et al. 1978):

$$
\begin{aligned}
1 \text { bushel corn } \rightarrow 2.6 \text { gal ethanol } & +16.8 \mathrm{lb} \text { distiller's dried grain (DDG) } \\
& +16.4 \mathrm{lb} \mathrm{CO}_{2} \\
& +5.6 \mathrm{lb}_{2} \mathrm{O}
\end{aligned}
$$

The DDG can be a valuable byproduct since it is a high-protein animal feed. The carbon dioxide also can be recovered for beverage use or for making dry ice.

The energy balance for ethanol fermentation depends upon the processing technique. The conventional processing technique used by most beverage alcohol distiliers was evaluated for energy consumption for ethanol production, as well as newer processes by ACR, Katzen, and Chemapec.

Although the figures for the Chemapec process shown in Table 3.4 are tentative, it appears to be one of the most energy-efficient processes for producing ethanol from starch hydrolysis. However, the newer processes featuring energy-saving innovations are also net energy producers. Energy balances indicate that the conventional technology requires more energy to produce the alcohol than is obtained from the products.

Full plant design details for the Chemapec process were not available; however, it can be described generally. The energy-savings innovations for the Chemapec process include 1) the separation of the starch portion of grain from nonfermentable materials before fermentation is begun, 2) fermentation done on 
TABLE 3.4. Proçess Energy Balances for Ethanol Production from Starch Hydrolysis $\left(10^{3}\right.$ Btu/gal Et0H)

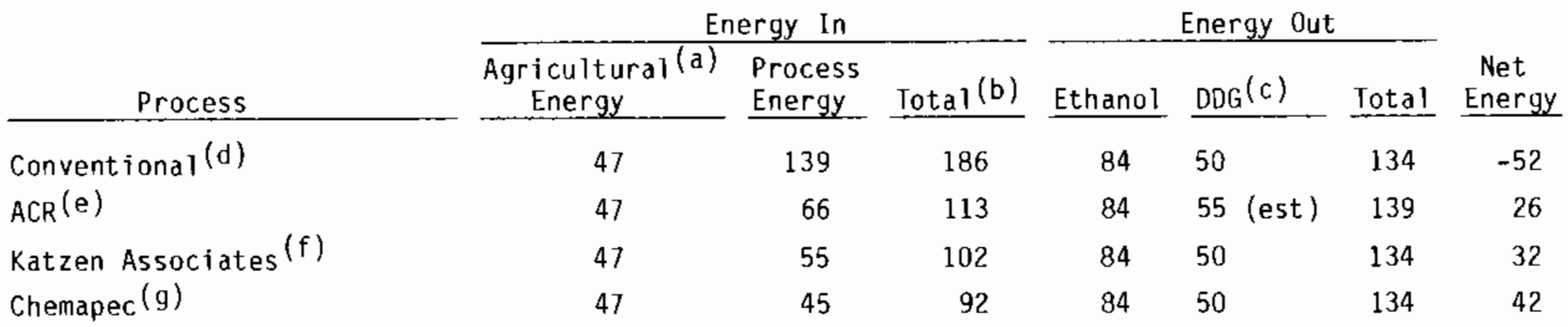

(a) The energy required for fertilizers, farm fuel use, and transportation is included.

(b) This value does not include the feedstock energy of corn because corn is not directly used as fuel. The sources of energy are coal for steam production and electricity.

(c) The energy of $D D G$ is fully counted as output energy since it could be burned, but it is more economical tó seli as animal feed.

(d) Based on David et al. (1978), Smith and McCullough (1980), and Chambers et a). (1979).

(e) Based on Chambers, et al. (1979), Smith and McCullough (1980), and ACR Company (1980). The energy for capital equipment included in ACR's estimates is excluded for consistency and the heating value of $0 D G$ is upgraded to reflect a completely dry product.

(f) Based on Smith and McCullough (1980); Chambers, et a1. (1979); and Paul (1980).

(g) Based on Sinith and McCullough (1980). This estimate assumes both thermal compression and methane recovery are used in plant design. 
a continuous basis with continuous vacuum evaporation of the fermentation mixture, and 3) production of methane from anaerobic digestion of process waste streams used to fuel the plant boiler.

Ethanol Production from Hydrolysis of Cellulosic Wastes

Ethanol can be produced from cellulose, as well as from starch, since both polymers are made up of fermentable glucose units. There are much larger quantities of cellulosic wastes available than there are starch wastes (Sarbolouki and Moacanin 1980). In addition, use of cellulose does not divert food crops for fuel production.

The production of ethanol requires separating pure celluiose from the rest of the biomass components, including hemicelluloses and lignins, before the feedstock is available for saccharification and fermentation. The cellulose feedstock typically is then either attacked with heat and dilute acid in several steps (D'Alessio and Blaunstein 1980, Paul 1980), or it is finely ground and enzymatically attacked (Paul, 1980; Emert, et al. 1980). (a)

Energy balances (see Table 3.5) indicate that current technologies for cellulosic waste hydrolysis require more process energy than the products contain, if the feedstock used for fuel rather than ethanol production is included in the process energy. The Gulf process, for example, requires only $51 \times 10^{3}$ Btu per gallon of ethanol for process energy utilities and diesel fuel. However, an additional $80 \times 10^{3}$ Btu per gallon of ethanol for process energy is supplied from byproducts. Although some of these technologies can be made self-sufficient with respect to fossil fuel consumption, their net energy balance is still negative.

\section{Methanol Production from Wood}

The production of methanol from wood is based on gasification, shift reaction, and the catalytically-controlled combination of the resulting $\mathrm{CO}$ and $\mathrm{H}_{2}$ gases. Major research efforts include the design of catalysts for the shift

(a) Information was also obtained from a Natick Research Laboratory internal document Enzyymatic Hydroloys is of Cellulosic Wastes to Glucose, 1975, by L. A. Spaño, J. Medeiros, and M. Mandets. 
TABLE 3.5. Process Energy Balance for Ethanol from Cellulose ( $10^{3} \mathrm{Btu} / \mathrm{gal}$ EtOH)

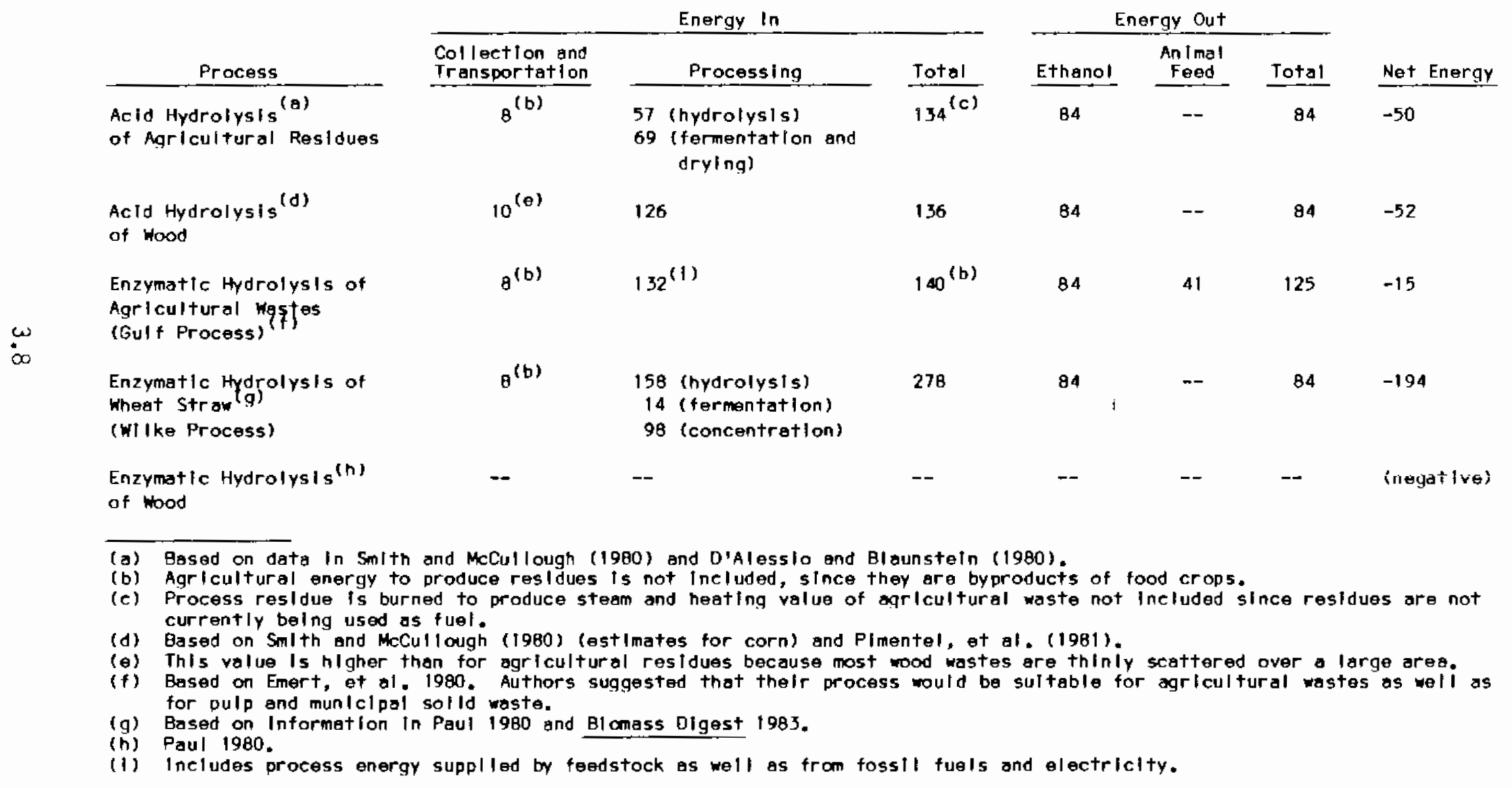


reaction and for the methanol production. Catalysts that show resistance to poisoning or clogging with char and that have greater activity and longer life are being developed (Mudge, et a1. 1983).

Producing methanol from gasification of wood shows promise and uses less energy than converting the wood to ethanol. A design by Chem Systems claims to require $2200 \mathrm{~kW} / 1000 \mathrm{dry}$ tons wood, over and above the recoverable energy supplied by the wood feedstock (D'Alessio and Blaunstein 1980). Since details about this system were unavailable, however, the process energy used in the energy balance (see Table 3.6) was based on data obtained from a pilot plant designed and operated by PNL (Mudge, et al. 1983; Mudge, et al. 1981).

Methanol production shows a slight net energy gain. The process energy is nearly all supplied by wood and byproduct char. In this process, char is not counted under "energy out" as a byproduct, although all the other energy balances list byproduct energy as an output credit. This is because the char is recycled, so its energy value is included as a credit in the process energy. The value obtained for net energy is not affected by counting char against process energy rather than as a byproduct.

TABLE 3.6. Process Energy Analysis for Methanol from Wood Residues(a)

\begin{tabular}{lcc} 
Item & Energy, $10^{3}$ Btu/gal methanol \\
\cline { 2 - 2 } Collection and chipping & 5.4 \\
Transportation, $6 \mathrm{mi}$ & $\underline{.6}$ \\
Process energy $(\mathrm{b})$ & 63.6 \\
Total energy in & $\frac{64.8}{64.8}$ \\
Methanol & 1.2 \\
Total energy out &
\end{tabular}

(a) Based on a $2000 \mathrm{dry}$ ton/day plant producing 1000 ton/day methanol

(b) Energy value of raw wood input not contained in product energy + electrical energy + diesel fuel energy. 


\section{Gasification of Wood}

Except for the catalysts, the production of fuel gas by wood gasification is similar to the production of methanol and uses an equivalent amount of energy. Currentiy, wood gasification technology is limited and slow (Mudge, et al. 1983). The state-of-the-art procedure uses a fluidized bed gasifier and a catalyst designed to promote formation of the desired products.

An energy balance, shown in Table 3.7, has been calculated for a new gasification process developed at PNL (Mudge, et al. 1983). This pilot plant operates on sawdust at $10 \mathrm{~atm}$ and $1382^{\circ} \mathrm{F}$ with added steam, and uses a specially designed trimetallic catalyst. Processing energy includes utilities requirements and wood used for heating rather than feedstock.

Using the best technology, gasifying biomass has become economical if a collected supply and a local market are available. An earlier energy balance on the same process extrapolated to a 2000 ton/day gasification plant gives a net energy gain of $2.1 \times 10^{3}$ Btu/lb of wood (Mudge 1981) based on the same assumptions; process energy remained unchanged but, product yields were improved.

IABLE 3.7. Energy Balance for Wood Gasification(a)

\begin{tabular}{|c|c|}
\hline Item & $\begin{array}{c}\text { Energy, } 10^{3} \mathrm{Btu} / 1 \mathrm{~b} \\
\text { wood Feedstock }\end{array}$ \\
\hline Collection and chipping & 0.27 \\
\hline Transportation, 6 mi & 0.03 \\
\hline Process energy & 3.10 \\
\hline Total energy in & 3.40 \\
\hline Char, $10 \%$ yield & 1.32 \\
\hline Gas & $\underline{5.90}$ \\
\hline Total energy out & 7.22 \\
\hline Net positive energy & 3.82 \\
\hline
\end{tabular}

(a) Excludes the heating value of the feedstock, but includes the energy content of the char. 


\section{Thermochemical Conversion of Biomass to Liquid Fuels}

Pyrolysis and direct liquefaction are the two major types of thermochemical conversion processes that produce a liquid fuel from biomass. Pyrolysis processes typicaliy require dry feedstock, high temperatures, and short residence times; they are frequently performed at reduced pressures (Pober and Bauer 1977). Liquefaction processes typically utilize wet feedstocks, lower temperatures, longer residence times, and high pressures (Donovan, Molton, and Demmitt 1981). Both processes produce an oil with moderate heating value, relatively high oxygen content, and poor storage stability. The byproducts of pyrolysis include char in relatively high yield and a low Btu gas; for liquefaction, they include char in lower yield and an aqueous phase with some dissolved polar compounds.

Most process development work is being done on a laboratory scale. Approximate energy calculations have been made for a laboratory-scale batchtype process for sewage sludge liquefaction that was developed at PNL (Donovan et al. 1980). Under these conditions, $4.84 \times 10^{3}$ Btu is needed to convert 2.2 ib (1 kg) of sludge, dry basis, to products containing a total energy of $14.1 \times 10^{3} \mathrm{Btu}$. The only pilot plant for wood liquefaction does not yet have energy balances. (a)

Pyrolysis processes of wood have been under sporadic development since the latter half of the 19th century (Molton and Demmitt 1977), but energy analyses could not be found for any pilot plant currently in operation. Liquefaction may turn out to conserve more energy than pyrolysis, since the feedstock does not require drying. Although liquefication processes are at a less developed stage than fermentation and gasification processes, they do have the potential to be net energy producers. However, the high oxygen content of the product fuel oil limits its usefulness unless it is hydrotreated. Further information in thermochemical conversion is needed to develop energy analyses.

(a) Personal communication from D. C. Elliot, PNL. 


\subsubsection{Current Potential Energy Savings from Bio-derived Fuels}

The following assumptions were made for this analysis: 1) harvested grain, agricultural residues, and urban wastes are used to produce ethanol; 2) agricultural residues, urban wastes and forest and mill wastes are gasified to medium-Btu gas or methanol; and 3) anaerobic bacteria convert manure and sewage to methane.

Energy balances described previously for appropriate production processes are used to calculate the current potential for "ossil energy savings from bioderived fuels. Several technologies are evaluated for ethanol production, but the process with the largest net energy gain is atilized as the basis for calculations.

The amount of thermal energy currently available in the United States from biomass is about 12.0 quads (see Table 3.8 ). However, only about .29 quads, or $1 \%$ of liquid fuel and 2.84 quads (or 16\%) of gaseous fuel used in this country in 1982. could be replaced by biomass-derived fuels (see Table 3.9). These

TABLE 3.8. Available Biomass Sources and Energy Values, 1980

\begin{tabular}{|c|c|c|}
\hline Source & $\begin{array}{l}\text { Energy va lue } \\
\text { (in Quad) }\end{array}$ & $\begin{array}{l}\text { Quantity, } \\
\text { short ton } \\
\end{array}$ \\
\hline Harvested grain & $.8^{(b)}$ & .06 \\
\hline Agricultural residue (collectible) & 6.4 & .4 \\
\hline Forest and mill wastes (collectible) & 1.6 & .1 \\
\hline Urban wastes & 1.4 & .2 \\
\hline Manure and sewage & 1.8 & .25 \\
\hline & 1.2 .0 & 1.01 \\
\hline
\end{tabular}

(a) Figures for harvested grain come from Pimentel et al. 1981; all others from Sarbolouki and Moacanin 1980, and Sheppard and Young 1983.

(b) Total crops equal $3.70 \times 10^{8}$ short tons (Pimentel et al. 1981). 56 1b/bushel was assumed (David et a1. 1978), and 350,000 Btu/bushel (David et al. 1978, Chambers et al. 1979). Of the 4.6 quad of total grain produced, only one sixth, or .77 quads are surplus and available for fuel (Chambers et al. 1979). 
TABLE 3.9. Amount of Fuel that Could be Produced from Biomass

$\frac{\text { Fuel Type }}{\text { Ethanol }} \frac{\text { Source }}{\text { Hydrolysis of surplus grain }}$

avallable

Net Fuel

Produced, Quads

.24

Gaslfleation and conversion of 50x of all agrlcultural, wood, and urban wastes evollable
1. There are $3.70 \times 10^{8}$ short tons of graln produced, of which $6.16 \times 10^{7}$ short tons are surplus. Since 1 bushel of graln gives $2.6 \mathrm{gal}$ ethanol and 16.8 lbs DDG (David et al. 1978). and assuming $56 \mathrm{lb} / \mathrm{bu}$ (David at al, 1978), 84,000 Btu/gal ethanol (Chambers, et al. 1979), and 7740 Btu/lb DDG CDavid et al. 1978, Chambers, et al. 1979), then $6.16 \times 10^{7}$ short tons of graln ylelds $5.72 \times 10^{9}$ gel ethanol and $3.69 \times 10^{10}$ I bs DDG, wh a combined energy content of $7.7 \times 10^{14}$ Btu. From this figure the collection energy of 47,000 Btu/gal ethanol (Table 3.4), which is $2.57 \times 10^{14}$ Btu for $5.72 \times$ $10^{9}$ gal ethanol, was subtracted. The processing energy of 45,000 Btu/gal ethanol (Table 3.4), which is $2.57 \times 10^{14}$ Btu for $5.72 \times 10^{9}$ gal ethanol, was also subtracted. The net energy Is therefore $\left(7.7 \times 10^{14}\right)-\left(2.69 \times 10^{14}+\right.$ $2.56 \times 10^{14}$ ) $=2.4 \times 10^{14}$ Btu.

2. The amount of methanol that can be obtained from halt of the avallable agricultural, urban, and forest waste available Is calculated as follows. The yield of methanol for the mixture is assumed to be the same as for wood residues. The quantity of 50 of these wastes avallable is estimated to be $3.5 \times 10^{8}$ short tons/yr (Sarboloukl and Moacanin 1980; Sheppard and Young 1983). The yleid of methanol is .50 lb per pound of dry blomoss, and the methonol has an energy content of $9.82 \times 10^{3}$ Btu per pound of mathanol (Mudge, et al. 1981). The methenol energy whlch can be obtalned therefore is about $3.43 \times 10^{15}$ Btu. The energy required for processing, collecting, chlppling, and transporting the blomass is $9.63 \times 10^{3}$ Btu per pound of methanol produced; this includes the credit for using byproducts as a fuel. This energy requlrement is subtracted from the product methenol energy. The net energy whlch can be 


\section{TABLE 3.9. (contd)}

Net Fuel

Fuel Type

Methanol (contd)

Gas

$\stackrel{\omega}{\vdots}$
Gasiflcation of 508 of all

agricultural, wood and urban

wastes avallable
Aneeroblc digestion of sewage and manure obtalned from conversion of $50 x$ of dry agricultural, forest, and urban wastes to methanol is therefore.05 $x$ $10^{15}$ atu.

3. The amount of gas that can be obtained from the other half of the avallable agricultural, urban, and forest wastes is calculated as follows. Ory weight of these wastes is $3.5 \times$ $10^{8}$ tons/yr. Yields of gas and char from the $m / x+u r e$ are assumed equal to ylelds from wood. The yleld of gas is $16.0 \mathrm{scf} / 1 \mathrm{~b} \mathrm{dry}$ wod, and the gas has a heeting value of $361 \mathrm{Btu} / \mathrm{sct}$ (Mudge, et al. 1983). The yleld of char is $10 \%$ of the dry rood lght, and has a heatlng value of $1.3 \times$ $10^{4}$ Btu/lb. Thei energy whlch can be obtalned therefore is $5 \times 10^{15} \mathrm{Btu}$. The energy required for processing, tronsporting, collecting, and chlpping the blomass $1 \mathrm{~s} 3.40 \times 10^{3}$ Btu/lb dry wood; this energy requirement must be subtracted from the product gas energy. The net energy that can be obtained frum gastilcatlon of 50 of dry agrlcu!tura!, forest, end urban wastes, therefore, is $2.6 \times 10^{15}$ etu.

4. Sewage and nanure can be converted to methane by anaerobic digestion (see Section 5.3 on pollution control). The totel energy shown in Table 3.6, 1.8 quad/yr, represents a total welght of $2.5 \times 10^{8} \mathrm{dry}$ tons/yr. Since one ton of dry semage and manure can produce about $3.12 \times 10^{6}$ Btu of methane, the energy value of the methane would total about .78 quad/yr. Collection energy is requited for manure, although not for urban sewage, and is estimated to be simllar to agricultural residue collection at $1.9 \times 10^{5}$ Qtu/ton. Processing eneray would be about $2.0 \times 10^{6}$ 
TABLE 3.9. (contd)

Net Fuel

Produced, Quads

$\frac{\text { Fuel Type }}{\text { Gas }(\operatorname{con} t d)}$

i
Total Ilquid

fuel replacement

\section{Total gas}

fuel replacement

Grand Total
Source

.29

$\underline{2.84}$

3.13
Btu/ton (EPA 1979). The net energy that wuld be avallable from anaeroblc digestion of sewage and manure would be about .24 quads/yr. 
numbers are much smaller than those shown in Table 3.8 because production, collection, and processing energy have been subtracted.

The calculations for determining the fuels available from biomass are described in Steps 1 through 4 in Table 3.9 .

\subsubsection{Research Needs for Fuels Production}

There is a large discrepancy between the amount of thermal energy originally available in the biomass and the amount of energy available after conversion to liquid or gaseous fuels. Although some processes are net energy producers, the net energy gain-is only about half of the fuel value of the products even in the best cases. This illustrates the need for research to increase the process energy efficiency of biomass conversion processes.

Several energy savings developments could reduce process energy requirements. These include advanced separations technologies to concentrate and purify products in liquid streams and more selective gasifier catalysts.

\subsection{BIOMASS AS A CHEMICAL FEEDSTOCK}

Figure 3.1 illustrates the structure of the bulk chemicals industry. The chemicals industry currently produces several thousand products and is comprised of several distinct categories: resources, feedstocks, primary chemicals, intermediate chemicals, and end use or specialty products. A resource is defined as a raw material as it enters the economy. After suitable treatment by physical or chemical means, the resource becomes feedstock. A primary chemical is the first homogenous material derivec from a feedstock. An intermediate chemical is synthesized from a primary chemical, and can be the source of an end product or another intermediate chemical. In many cases, a substance can be both an intermediate and an end product. For example, ethylene glycol is used as antifreeze (end product) and is also a precursor to polyester manufacture (intermediate) (Lipinsky 1978).

Currently the entire U.S. chemical industry consumes about $4 \%$ of petroleum, $10 \%$ of natural gas, $21 \%$ of natural gas liquids, $6 \%$ of coal and $8 \%$ of electricity. In 1982, total energy use was about 5.6 quads. If a $33 \%$ 


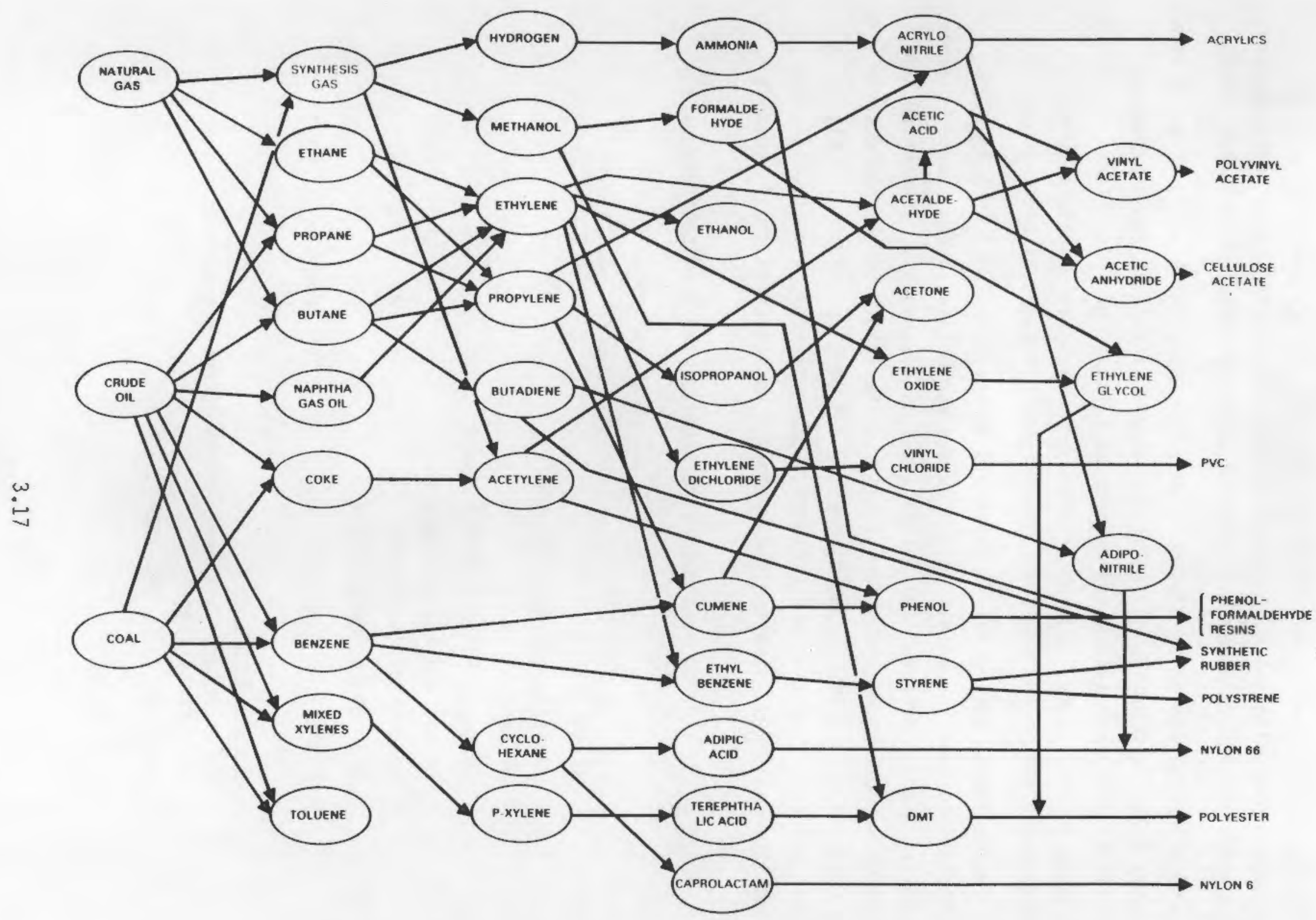

FIGURE 3.1. Structure of Organic Chemicals Industry 
efficiency is assumed for electricity, the total energy consumed is actually 8.9 quads. Approximately 2.5 quads of energy can be attributed to feedstock consumption and the remainder is utilized during processing 1983).

Major energy consuming product groups for the chemicals industry are shown in Table 3.10. Production of industrial organic chemicals and nitrogenous fertilizers from biomass-derived feedstocks (instead of fossil feedstocks) was evaluated in this study. Currently production of these materials consumes approximately $50 \%$ of the fuels and electricity purchased by these groups.

The following categories of chemicals were not included in this study: industrial inorganic chemicals, plastics and synthetics, drugs, soaps, cleaners and toilet goods, "others," and paints and allied products. Industrial inorganics do not use hydrocarbon feedstocks, so they could not be replaced by biomass derivatives. Plastics and synthetics can be displaced indirectly by cellulosic products, but they are excluded because 1) impacts will be diverse, 2) facilities already exist for the synthetic counterparts and 3) product

TABLE 3.10. Energy Consumption Pattern for the Chemicals Industry

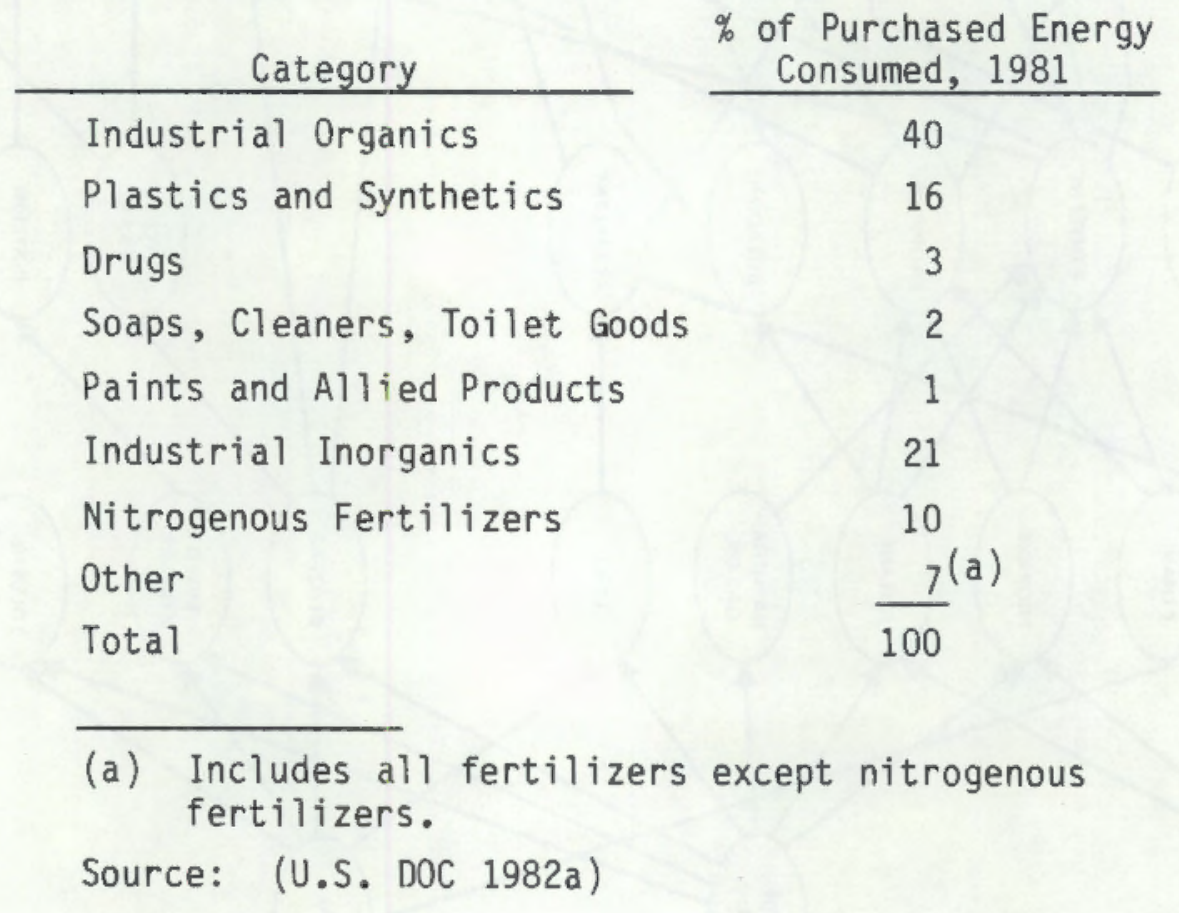


acceptance will hinder development. Although biotechnology is already causing massive changes in the drug industry, it was not included because energy consumption is minimal. Paints and allied products and the "others" category were also excluded because of low energy consumption and limited bioprocess applicability.

\subsubsection{Structure of Biomass-Based Chemicals Industry}

Industrial organic chemicals and nitrogenous fertilizers are the products with substantial domestic energy consumption that would primarily be affected by direct substitutions of biological derivatives. Hydrocarbon sources such as petroleum and natural gas are currently the primary feedstock for organic chemicals and nitrogenous fertilizers, but biomass feedstocks could replace all the fossil feedstocks used by the chemicals industry (0'Brien 1982). As a result, existing primary chemicals would be directly replaced by fermentation chemicais, phenol, or benzene. Current technologies could then be used for downstream processing of intermediates and end products (see Figure 3.2).

Direct imitation of petrochemicals by a biomass-based industry was analyzed in this study because it has the advantage of instant product acceptance and many existing opportunities for transformation to end-products. However, materials comparable to petrochemical derivatives can be found in nature. Indirect substitution of these materials would eliminate the process energy requirements for synthesis of polymers and complex intermediates from simple hydrocarbons. The analysis of the indirect substitution scenario would be much more complex and was therefore beyond the scope of this report. The recommendations from this analysis should still be applicable to both direct and indirect substitution scenarios because the production of both types of materials is similar.

In a biomass-based industry, direct substitution for primary chemicals could be accomplished by the methods shown in Figure 3.3. Cellulose and hemicellulose would be hydrolyzed to sugars that are converted to ethanol, isopropanol, and these alcohols would then be dehydrated and deoxygenated to ethylene, propylene, and butadiene and directly substituted for 


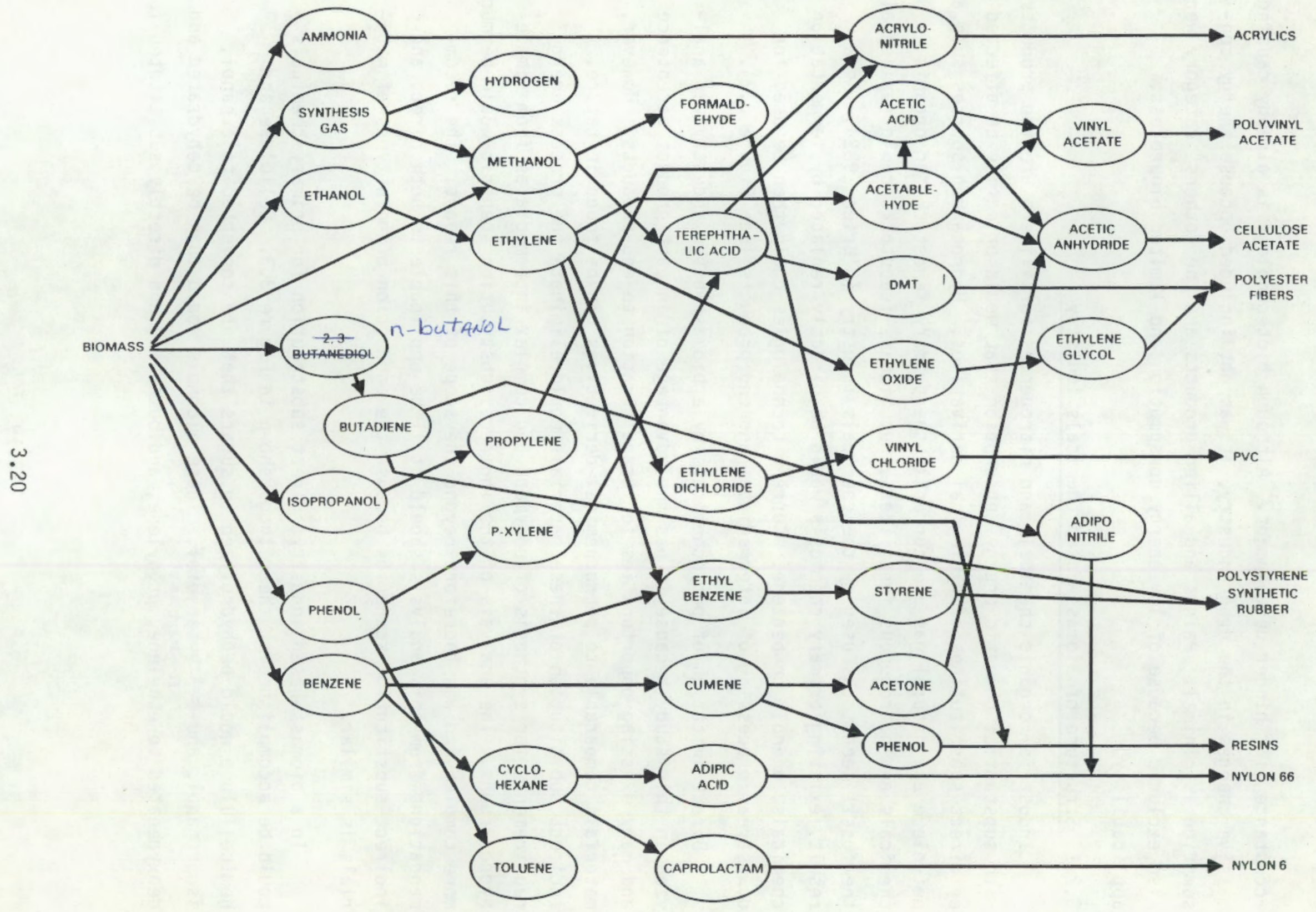

FIGURE 3.2. Biomass-Based Organic Chemicals Industry 


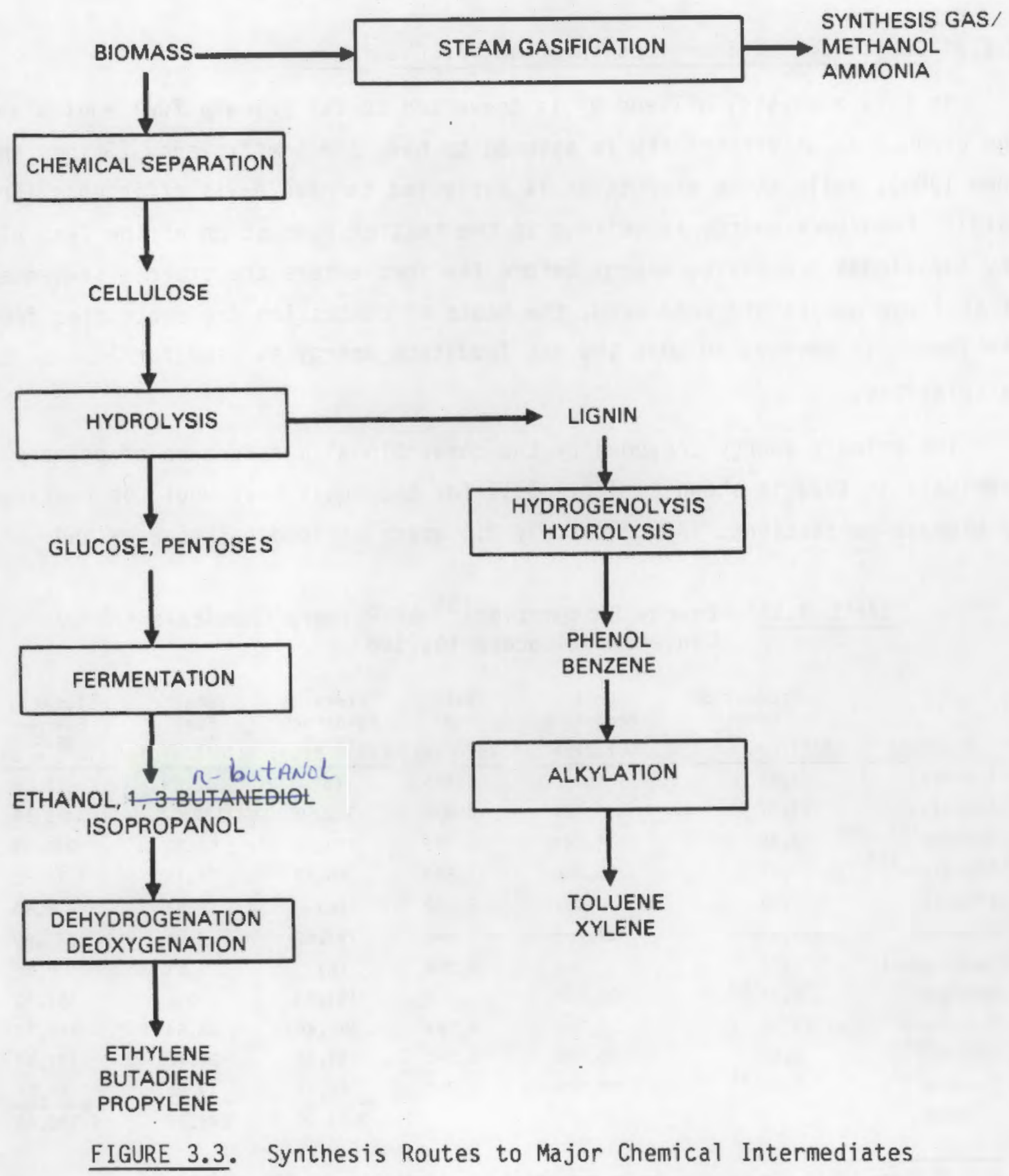

the fossil fuel derivatives. The residual lignin would be treated by hydrogenolysis and hydrodealkylation to yield phenol, benzene, and other mono-phenolic compounds, which could potentially be alkylated to toluene and xylene, although the technology is not yet available. Synthesis gas, ammonia, and methanol would be produced by steam gasification of biomass. 


\subsubsection{Comparison of Energy Consumption for Chemicals}

In this analysis, all energy is converted to its primary fuel equivalent. The production of electricity is assumed to have a $33 \%$ efficiency (Gaines and Shen 1980), while steam production is estimated to have a $71 \%$ efficiency (Brown 1979). Feedstock energy is defined as the heat of combustion of the feed plus any additional processing energy before the feed enters the process sequence. If fuel byproducts are recovered, the heats of combustion are subtracted from the feedstock energy, so that the net feedstock energy is used for calculations.

The primary energy consumed by the conventional manufacture of primary chemicals in 1983 is shown in Table 3.11 for chemicals that would be replaced by biomass derivations. Approximately 2.1 quads of feedstock energy and

TABLE 3.11. Energy Consumption(a) of Primary Chemicals in Conventional Scenario, 1983

\begin{tabular}{|c|c|c|c|c|c|c|}
\hline Chemical & $\begin{array}{c}\text { Production } \\
\text { Level } \\
\text { (Billions of } 1 \mathrm{~b} \text { ) }\end{array}$ & $\begin{array}{c}\text { Unit } \\
\text { Feedstock } \\
\text { (B+u/lb) } \\
\end{array}$ & $\begin{array}{c}\text { Unit } \\
\text { Fuel } \\
(B+u / I b) \\
\end{array}$ & $\begin{array}{c}\text { Total } \\
\text { Feedstock } \\
\left(10^{12} \text { Btu }\right) \\
\end{array}$ & $\begin{array}{c}\text { Total } \\
\text { Fuel } \\
\left(10^{12} \mathrm{~B}+\mathrm{u}\right) \\
\end{array}$ & $\begin{array}{c}\text { Total } \\
\text { Eneray } \\
\left(10^{\text {Ey }} 2^{\mathrm{B}+u}\right) \\
\end{array}$ \\
\hline Acetone & 1.87 & (b) & 6,463 & (b) & 12.09 & 12.09 \\
\hline Ammon i a & 27.37 & 11,435 & 6,455 & 312.98 & 176.67 & 489.65 \\
\hline Benzene ${ }^{(h)}$ & 9.48 & 18,947 & 6,363 & 179.62 & 60.32 & 239.94 \\
\hline Butadiene ${ }^{(f)}$ & 2.31 & 26,266 & 7,859 & 60.67 & 18.15 & 78.82 \\
\hline Ethanol & 1.10 & (c) & 8,032 & (c) & 8.83 & 8.83 \\
\hline Ethylene & 28.59 & 27,768 & 7,800 & 793.89 & 223.00 & $1,016.89$ \\
\hline Isopropanol & 1.21 & (b) & 4,555 & $(b)$ & 5.51 & 5.51 \\
\hline Methane & $6.35^{(d)}$ & 23,861 & 0 & 151.52 & 0 & 151.52 \\
\hline Propylene & 13.98 & 27,717 & 6,784 & 387.48 & 94.84 & 482.32 \\
\hline Xylene & 5.57 & 23,686 & 5,293 & 131.93 & 29.48 & 161.41 \\
\hline Toluene & $3.76^{(\theta)}$ & 18,379 & 5,293 & 69.11 & 19.90 & 89.01 \\
\hline Total & & & & 2087.20 & 648.79 & $2,736.00$ \\
\hline
\end{tabular}

(a) Primary fuels are assumed to be converted to electricity at $33 \%$ efficiency and to steam at $71 \%$ efficiency.

(b) Feedstock included in propylene and benzene.

(c) Feedstock included in ethylene.

(d) Amount required for methanol, acetylene, and small use hydrogen manufacture.

(e) Does not inelude amount used to make benzene.

(f) Weighted average of energy requirements for butadiene produced as 1) a byproduct of ethylene manufacture and 2) as the desired product from dehydrogenation of butane or butene.

(g) Extracted from petroleum reformate.

(h) Weighted average of energy requirement of benzene produced by extraction from petroleum reformate and by toluene disproportionation. 
0.5 quads of process fuel are consumed. Feedstock values in Table 4.11 include some process energy so they may be larger than the values reported in other references. Energy balances from published sources (Gaines 1980; Brown 1979) were used, and production data were derived from C\&E's Top 50 List (Chemical and Engineering News, June 11, 1984).

Energy balances derived by Donaldson and Culberson (1983) were utilized to calculate the process energy consumption of biomass-based chemicals shown in Table 3.12. Production levels reflect the amount of biomass-based chemicals required to produce downstream chemicals in quantities equivalent to that of the fossil-based scenario in 1983.

The process energy required for the production of major primary chemicals from biomass is estimated to be approximately 1.67 quads. Since the wood is assumed to be a residue, agricultural energy to grow the wood is not included. If the fossil energy to collect and transport the wood (293 Btu/ib of wood) is included, the caiculated process energy requirements for the biomass-based chemicals industry must be increased from 1.67 to 1.80 quads.

Approximately 439 billion lb, or 0.22 billion tons, of wood would be required to produce the chemical feedstocks. If the feedstock energy of 0.22 billion tons of dry wood at $8000 \mathrm{Btu} / 1 \mathrm{~b}$ is included, total feedstock energy consumed by the biomass-based scenario is 3.51 quads.

\subsubsection{Research Needs for Biomass as a Feedstock for Chemicals}

A11 the 2.1 quads of feedstock energy required for the synthesis of

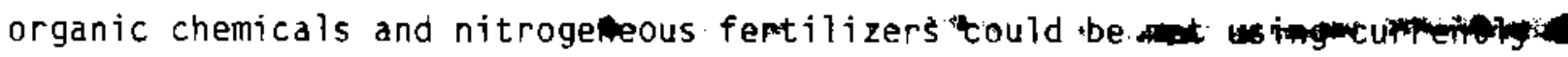
available supplies of wood and wood residues, neglecting additional process fuel requirements. Crop residues could also be used, but they were not analyzed in this study. The saving is still desirable despite the fact that burning the equivalent quantity of wood feedstock directly could provide 3.51 quads of energy; however, chemical production is more desirable because the doliar value of a feedstock as a chemical is about three times its value as a fuel (Palsson et al. 1981). In addition, the use of biomass frees the chemical industry of its reliance on fossil sources of feedstock and has many ecological benefits, such as the formation of less caustic effluents. 
TABLE 3.12. Energy Consumption(a) for Biologically-Based Chemicals

\begin{tabular}{|c|c|c|c|c|c|}
\hline \multirow[b]{2}{*}{ Chemical } & $\begin{array}{c}\text { Production } \\
\text { Level }\end{array}$ & $\begin{array}{c}\text { Unit } \\
\text { Feedstock }\end{array}$ & $\begin{array}{l}\text { Unit } \\
\text { Fuel }\end{array}$ & $\begin{array}{l}\text { Total } \\
\text { Feedstock }\end{array}$ & $\begin{array}{l}\text { Total } \\
\text { Fuel }\end{array}$ \\
\hline & (billions of lb) & (per lb product) & $(B+u / I b)$ & $\left(10^{9}\right.$ ib $)$ & $\left(10^{12} \mathrm{BTu}\right)$ \\
\hline Acetone & $1.87^{(b)}$ & & & & \\
\hline Ammonia & 27.37 & $1.73 \mathrm{Ib}$ rood & 7,462 & 47.35 wood & 204.23 \\
\hline Benzene & $9.48^{(c)}$ & & & & \\
\hline$-1,-3$ - Eutamedtol & $4.81^{(m)}$ & 11.39 ID mood & 37.611 & 54.79 wood & 180.91 \\
\hline EthanoYtanEL & $47.62^{(d)}$ & $4.37 \mathrm{lb}$. & 15,327 & 208.10 wod & 729.87 \\
\hline Ethanol & $.71^{(b)}$ & & & & \\
\hline Ethylene & $27.92^{(e)}$ & & $4,000^{(k)}$ & & 111.68 \\
\hline I sopropanol & $17.84^{(f)}$ & 5.71 ib mood & $15,327^{(k)}$ & $10 \uparrow .87 \mathrm{mood}$ & 273.43 \\
\hline Synthesis Gas & $17.03(\mathrm{~g})$ & 1.59 ib wood & 1,390 & 27.08 wood & 23.67 \\
\hline Phenol & $13.58^{(h)}$ & 4.95 tb lignin & 4,452 & 67.22 lignin & 60.46 \\
\hline Prooylene & $11.85(1)$ & & $4,000^{(k)}$ & & 47.40 \\
\hline Tolvene & $3.76^{(\mathrm{J})}$ & & $4,000^{(k)}$ & & 15.04 \\
\hline Xylene & $5.57^{(\mathrm{j})}$ & & $4,000^{(k)}$ & & 22.28 \\
\hline & & & & $439.19 \bmod$ & $1,669.0$ \\
\hline & & & & 67.22 lignin & \\
\hline
\end{tabular}

\footnotetext{
(a) Primary fuels are assumed to be converted to electricity at 336 efficiency and steam at $71 \%$ efticiency. $\quad n$-butaniol

(b) Produced as byproduct in 1,3 - botaneditol production.

(c) Produced as byproduct in phenol production.

(d) includes amount necessary to satisfy ethylene teedstock requirement.

(e) By dehydration of ethanol, 0.67 billion lb of ethylene feedstock not needed to make ethanol.

(f) includes amount necessary to satisfy propylene feedstock requirement.

(a) Includes amount requlred in conventional scenario plus additional amount for alkylation of phenol to toluene and xyiene.

(h) Amount required to manufecture toluene and xylene at $80 \%$ yield.

(i) By dehydration of isopropanol, 91 billion 1 b propylene not needed to make I sopropanol, 1.22 billion lb not needed to make cumene.

(j) Vla elkylation of phenol or benzene.

(k) Estimate based on published partial data and/or data from similar processes.

(1) 3.36 bililion lb Toluene got need to make benzene.

(m) Amount to make $2.31 \times 10^{9}$ lb butediene.
}

Currently, the process fuel requirements of a biomass-based chemical industry are estimated to exceed conventional process energy requirements by 1.02 quads. If collection and transportation energy for wood is included, the estimated additional energy consumption increases to 1.15 quads.

Improvements to bioprocess technologies are necessary to change the energy efficiency and allow economic entry into the chemicals manufacturing industry. Separation costs are high for fermentation processes because of the 
dilute nature of the products. Bioreaction systems that yield higher concentrations could be developed. Separations costs could also be reduced by the development of less energy-intensive technologies such as membranes.

Energy for gasification reactions to produce $S N G$, ammonia, and methanol could be reduced by improved gasifier designs and also by the development of biocatalysts resistant to high temperatures and pressures. Biocatalysts (described further in Section 4.0) could also reduce energy requirements for fossil-based processes.

Although not analyzed in this report, a large potential for energy-savings exists from the development of biomass-derived substitutes for petroleum-based plastics, fibers, rubbers, and resins. Large complex molecules provided by nature could theoretically be converted directly to intermediates and final products with minimal processing. 


\subsection{APPLICATIONS FROM GENETIC ENGINEERING}

The development and improvement of genetically-engineered materials should provide industry with revolutionary new techniques for the production of goods and services. The large-scale implementation of these techniques would result in substantial energy savings over conventional scenarios.

The developments in genetic engineering that will affect major industries are discussed in the following section. Energy-saving applications are evaluated for fuels production, chemicals production, mining, pollution control, agriculture and food processing. First, the current consumption of primary energy is discussed for each industry. Second, specific applications of genetically-engineered materials are identified. Then, the potential energy savings resulting from the large-scale implementation of genetically-engineered materiais is determined. Finally, recommended areas for research are identified.

\subsection{FUELS PRODUCTION}

Bio-derived fuels do not have a large-scale potential to substitute for fossil fuels, given the current process efficiencies and yields of biomass. The potential for genetic engineering to improve the feasibility of large-scale fuels production from biomass is discussed in the following section. Technologies for the production of bio-derived fuels are discussed in Section 3.0.

\subsubsection{Current Limitations to Large-Scale Fuels Substitution}

Based on PNL calculations (see Appendix B), the 26.9 quads of liquid fossil fuels consumed in 1982 could be replaced by the manufacture of 45 quads of methanol or 55 quads of ethanol. The excess bio-derived fuel must be produced to provide fuel for cultivation, fertilization, harvest, transportation, and processing of the biomass feedstock. Calculations indicate that growth of the required quantities of biomass for methanol production would require 1.82 billion acres of forestiand, or for ethanol, 2.85 billion acres of cropland. This is $253 \%$ more forestland or $792 \%$ more cropland than is currently available in the United States. 
If current yields of biomass feedstocks could be improved through genetic engineering, the land requirements for growth would be reduced. According to Edward S. Lipinsky and Dr. William Sheppard at Battelle Columbus Laboratories (BCL), genetic engineering could realistically be expected to improve current yields of plants by a factor of three. Table 4.1 illustrates the percentages of currently available U.S. 1 and that would be required for biomass feedstock production at current yields and three times the current yields. This anaiysis is based on the assumption that other energy inputs per unit of biomass output do not increase.

TABLE 4.1. Land Requirements for Biomass Production to Meet the 1982 Fuel Demand

\begin{tabular}{|c|c|c|c|c|c|c|}
\hline \multirow[b]{2}{*}{ Fuel } & \multirow{2}{*}{$\begin{array}{l}\text { Production } \\
\text { Required for } \\
1982 \text { Fuel } \\
\text { Demand, Quads }\end{array}$} & \multirow{2}{*}{$\begin{array}{l}\text { Biomass } \\
\text { Feedstock } \\
\text { Required } \\
\text { (tons) }\end{array}$} & \multicolumn{2}{|c|}{$\begin{array}{l}\% \text { of } 50 \text { State Area } \\
\text { for Growth (b) }\end{array}$} & \multicolumn{2}{|c|}{$\begin{array}{l}\text { \% of Currentiy } \\
\text { Available U.S. Land }\end{array}$} \\
\hline & & & $\begin{array}{l}\text { Current } \\
\text { Yields }(c)\end{array}$ & $\begin{array}{l}\text { Improyed } \\
\text { Yield d }\end{array}$ & $\begin{array}{c}\text { Current } \\
\text { Yield } \\
\end{array}$ & $\begin{array}{l}\text { Improved } \\
\text { Yieid } \\
\end{array}$ \\
\hline Ethanol & 26.9 & $7.1 \times 10^{9}$ & 124 & 41 & 792 & 264 \\
\hline Methanol & 26.9 & $9.1 \times 10^{9}$ & 78 & 26 & 253 & 84 \\
\hline SNG & 17.9 & $3.87 \times 10^{9(e)}$ & 34 & 11 & 108 & 36 \\
\hline
\end{tabular}

(a) Methanol and SNG are deriyed from wood biomass. Ethanol is derived from corn.

(b) 50 state area is $2.3 \times 10^{9}$ acres, of which $16 \%$ is cropland and $31 \%$ is forestland (Meyers 1983).

(c) Current yield for corn is as sumed to be 2.5 tons/acre of grain (Burwel1 1980) and for wood it is assumed to be 5 tons/acre of biomass (Meyers 1983).

(d) Estimated for genetically improved yield is 3 times current yield.

(e) Corn is grown on cropland, wood is grown on forestiand.

(f) Approximately $11 \%$ is for a methanol product to provide liquid fuels for growth and collection and $89 \%$ is for conversion to SNG.

\subsubsection{Potential Impact of Genetic Engineering}

To put this analysis in perspective, results are shown graphically in Figures 4.1, 4.2, and 4.3. Comparison of land requirements in the figures at current yields and three times the current yields illustrate that genetic engineering should improve the feasibility of large-scale fuel production from 


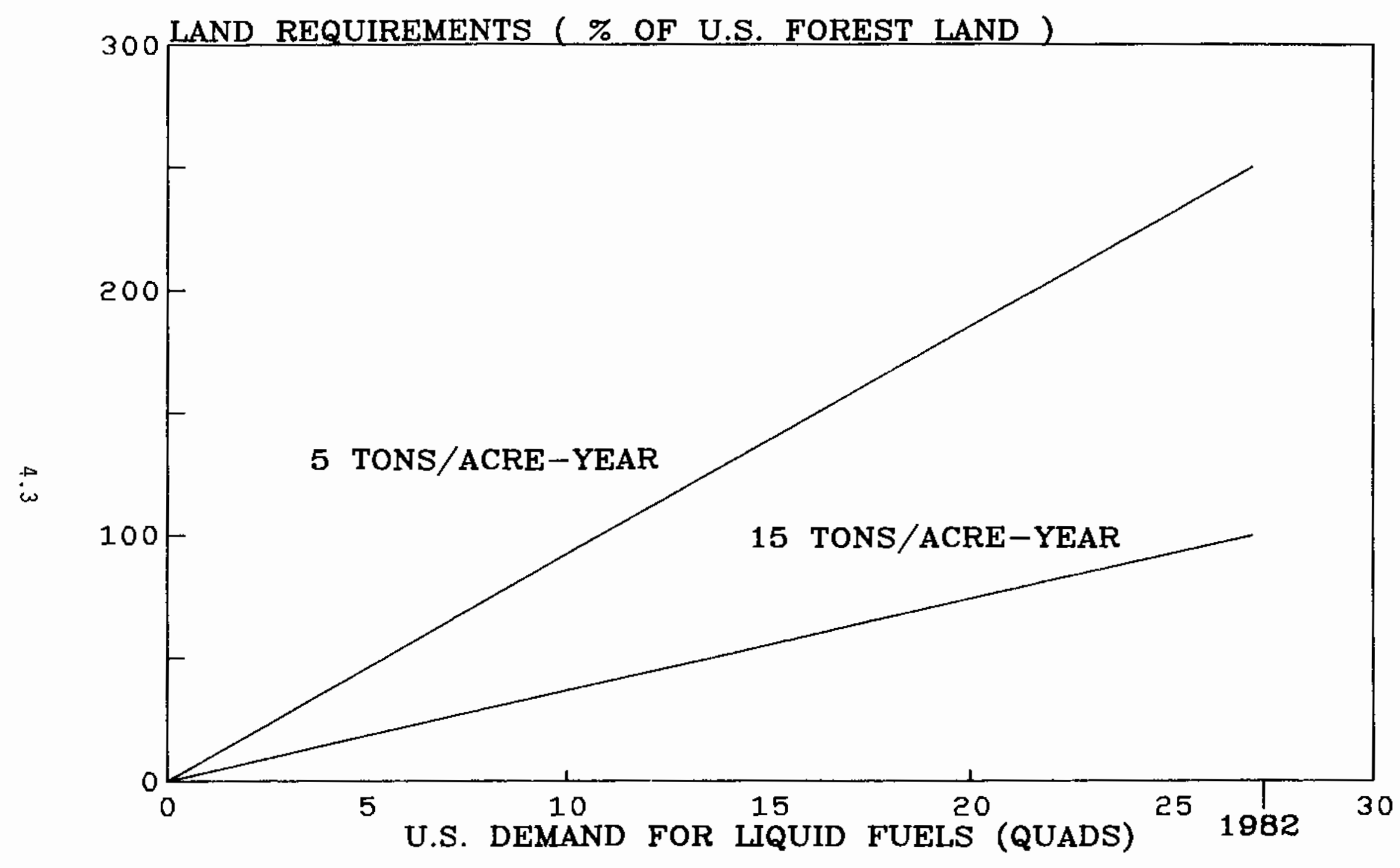

FIGURE 4.1. Potential Availability of Biomass to Provide Liquid Fuel from Methanol 


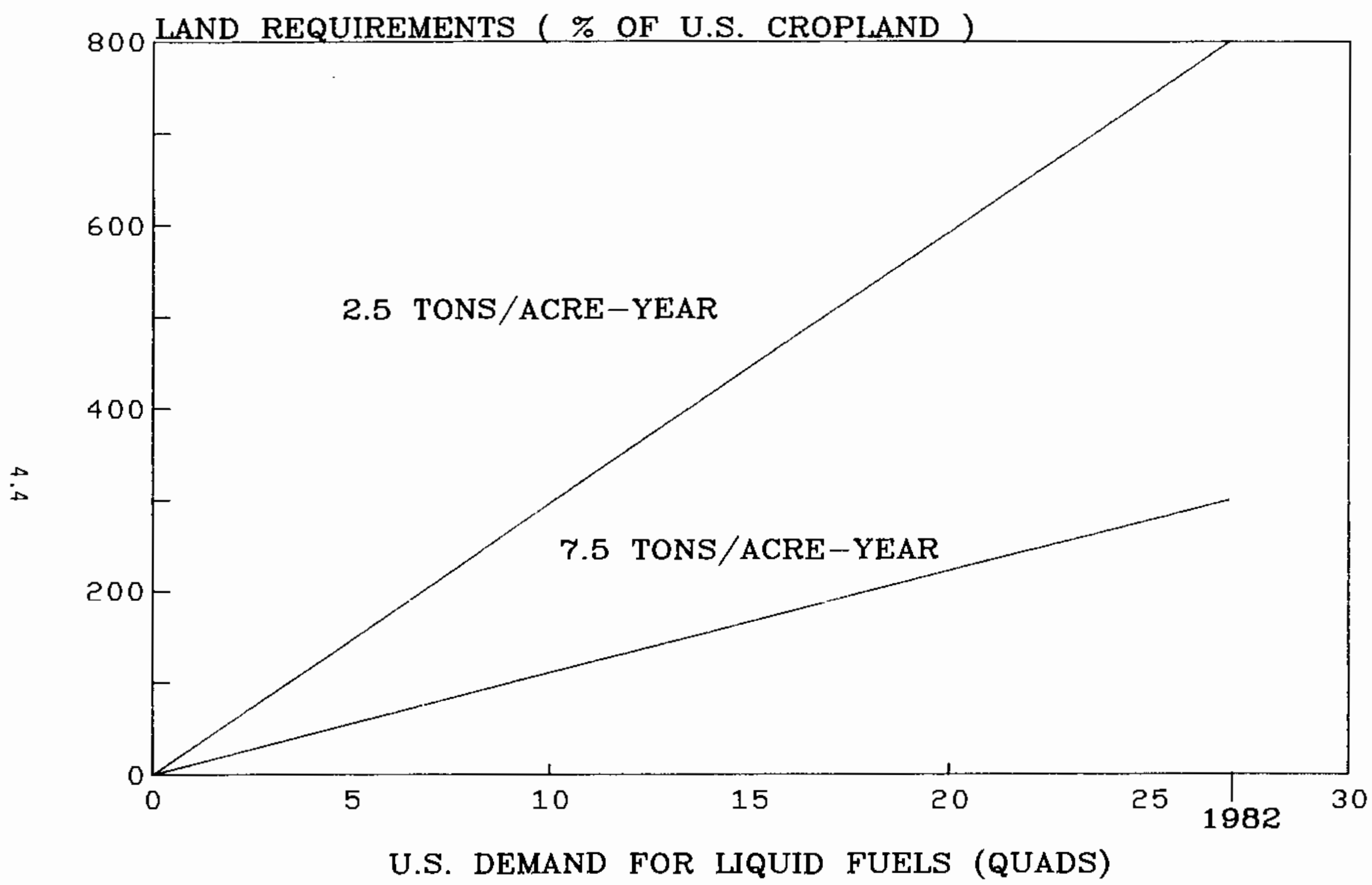

FIGURE 4.2. Potential Availability of Biomass to Provide Liquid Fuel from Ethanol 


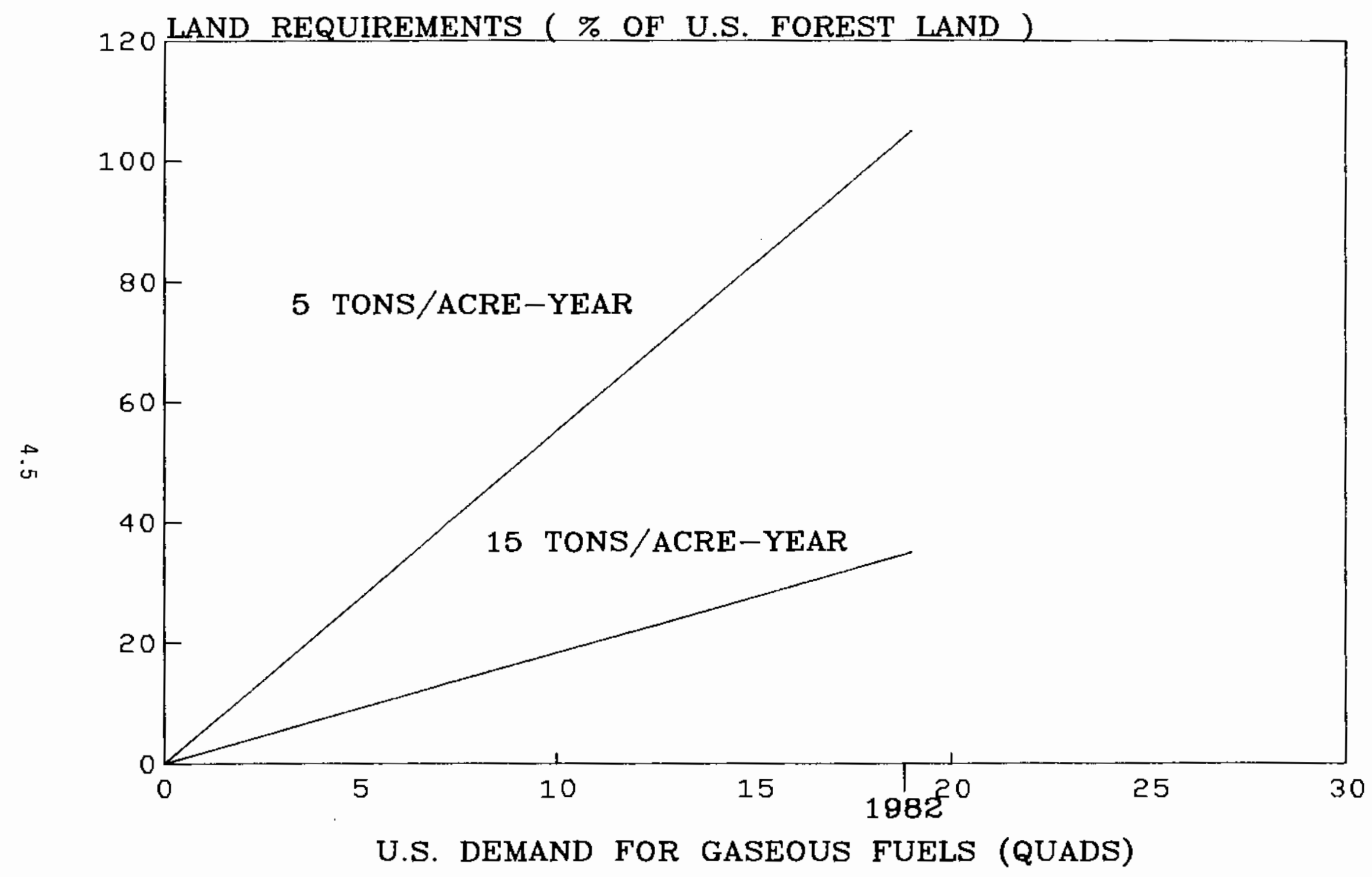

FIGURE 4.3. Potential Availability of Biomass to Provide Gaseous Fuel from SNG 
biomass feedstocks. It is unlikely, however, that the total fuel demand can be supplied using biomass feedstocks, although the potential for partial replacement is significant.

It is assumed in this analysis that yields of biomass feedstocks can be improved without significant increases in other energy inputs. Increasing yields will require a balanced program of genetic research to increase photosynthetic efficiency, biologically fixate nitrogen, and improve the water retention of soil. The development of any other traits that ensure consistent biomass yields despite the year-to-year variability of natural growing conditions would also increase the feasibility of large-scale biomass production.

Genetic engineering to improve the process efficiency of biomass conversion technologies would also reduce the land requirements for large-scale fuels production. Twice as much ethanol must be produced, for example, than the amount required to substitute for the fossil fuel demand. Process energy requirements could be reduced if the products streams could have higher concentrations of ethanol. Another way to reduce process energy is to improve the ability of the biomass feedstock to dry naturally in short periods of time. This has already been accomplished for several varieties of corn.

Energy for both gasification and fermentation of biomass could be reduced by the development of biocatalysts, which are discussed further in Section 4.2 . Development of enzymes that are stable at high temperatures and pressures could increase conversion efficiencies and reduce energy inputs, especially for the gasification process. Continued work on bioreactor designs that incorporate immobilized microbes and enzymes is also necessary.

\subsection{CHEMICALS PRODUCTION}

Current energy consumption for biomass-based chemicals production, discussed in Section 3.0, is prohibitive. The use of genetically-engineered materials could significantly reduce the energy consumed by the U.S. chemicals industry by promoting the feasibility of biomass feedstock and reducing process energy requirements. Several advantages of biosynthetic processes are described in the following paragraphs. Limitations to large-scale implementation of these technologies are also discussed. 


\subsubsection{Advantages of Bioprocessing}

In bioprocessing, microorganisms or the enzymes produced by microorganisms (biocatalysts) are used to convert raw materials to products. Biocatalysts are genetically-engineered materials that have particular energy-savings potential. Biocatalysts are enzymes or protein structures that expedite the conversion of a raw material to a product. These enzymes are usually produced by microorganisms and then purified. In many cases, the microorganisms can be added directly to the raw materials, where the cells produce the enzymes as a result of their genetic mechanisms.

Microorganisms and biocatalysts show great promise for both fossil-based and biomass-based industrial applications. Some biocatalysts can accelerate reactions up to 14 orders of magnitude, which is 4 to 6 orders of magnitude beyond the effect of most chemical catalysts. They are very specific in the products they synthesize, which inherently offers control over the products formed and decreases undesirable side products. As a result, separation and purification requirements are reduced, and this in turn reduces the need for disposai and management of pollutants.

Microorganisms and biocatalysts can carry out several steps of a synthetic process in one vessel, which eliminates the need for capital equipment for separation and purification of currentiy manufactured intermediates (Dunnil 1980). Therefore, most of the process energy used for the production of chemical intermediates could theoreticaliy be saved.

Whote cell or enzyme systems can be developed for existing processes or they can be engineered for novel synthesis routes. Revolutionary developments from genetic engineering, such as microbial processes that convert low-value materials such as biomass, coal, or even toxic wastes directly into end products, are theoretically possible. These processes would eliminate the need for energy to depolymerize large complex molecules available from nature into the small chemical building blocks that must be repolymerized into chemical intermediates or end products. 


\subsubsection{Limitations to Implementation of Bioprocesses}

Utilization of biocatalysts for industrial reactions will not be realized without developments in genetic engineering and bioreactor design. Catalyst systems that immobilize whole cells or enzymes must be designed to withstand the harsh conditions of typical chemical synthesis environments. This must be accomplished without affecting the stability or the catalytic properties necessary for economic commercial application of bioprocesses in the chemicals industry.

Enzymes and support systems that are stable under high temperatures, high pressures, and acidic or caustic conditions are an important research chalienge for processes that favor these equilibrium states. In addition, many important enzymes, such as hydrogenase, nitrogenase, or fornate dehydrogenase cannot be exposed to air without loss of activity. Genetic engineering to develop enzyme counterparts that are stable in the presence of oxygen is a potential solution, along with the design of bioreactors that minimize the exposure of the enzyme to oxygen.

Scale-up problems related to large-scale bioreactor design must also be solved. Competitive chemical processes require high volumetric productivity to minimize capital investment. In traditional fermentation, processes minimize volumetric productivity because they are usually batch-fed. This allows high product concentrations to accumulate by letting the volumetric flow rate approach zero. However the use of highly active immobilized enzymes should make it possible for reactors to run continuously with high formation rates.

The development of bioreactor systems has been difficult to achieve because of engineering limitations and physical constraints. In an immobilized biocatalytic system, substances must diffuse from the bulk solution to the catalytic sites. As volumetric productivity increases, so do the diffusional requirements of the bioreaction system. Nutrients (in the case of whole cells) and substrates must be transferred to the catalytic site, while products and excess heat must be diffused back into the bulk solution. Without effective heat and mass transfer within an immobilized catalyst system, high enzymatic reaction rates cannot be achieved. 
To minimize diffusional limitations, continuous bioprocesses can currently be characterized by high voiumetric flow rates and low product concentrations. Bioprocessing research to maximize the concentration of the products leaving the reactor is necessary to reduce energy consumption for isolation and purification. Genetic engineering to reduce nutrient requirements and increase conversion efficiencies of biocatalytic reactions are potential solutions to these problems. Development of biocatalysts that are phobic toward the material produced would also increase diffusion rates.

\subsection{METALS MINING ANO RECOVERY}

Metal mining consumes about $7 \%$ of the energy used by the minerals industries. If we include the efficiency of electrical generation, energy used by metal mining (major group SIC 10) was about 0.25 quads in 1977. Preliminary reports indicate that energy use was less in 1982 than in 1977, but exact data are not yet available (Bureau of the Census 1984).

Major energy-consuming metal mining and recovery techniques that could use microbial methods include the leaching of copper, lead, zinc, uranium, gold and silver deposits. Recovery of these ores consumes about $45 \%$ of the energy used by industries in category SIC 10. In 1980, the amount of energy used to recover these ores, based on data in Tables 4.2 and 4.3 , is estjmated to have been about 0.17 quads. This includes the smelting and refining of copper, lead, and zinc and the refining of gold and silver, which are not included in industry category SIC 10.

\subsubsection{Bacterially-Assisted Recovery Methods}

Two microbial interactions with metals that are of potential industrial importance are 1) microbial leaching of metals from ores and, 2) bioaccumulation of metals from dilute mixtures. The first method could be implemented on a large scale for the recovery of copper, uranium, lead, and zinc from vast quantities of low-grade solid materials. Bioaccumulation would be of primary importance for recovering higher value metals such as gold and silver from dilute waste streams. The potential production rates for the metais recovered 
TABLE 4.2. Process Energy Required per Ton Product ( $10^{6}$ Btu)

\begin{tabular}{|c|c|c|c|c|c|c|c|}
\hline & & Mining & Crushing/Grinding & Concentrating & Smelting & Refining & Total \\
\hline & Copper & $20.1^{(a)}$ & $29.4^{(a)}$ & $12.6^{(a)}$ & $29.5^{(b)}$ & $10.1^{(b)}$ & 101.7 \\
\hline & Lead (b) & 4.31 & 3.33 & 1.20 & 12.9 & 5.1 & 26.8 \\
\hline & $\operatorname{Zinc}(b)$ & 5.57 & 4.06 & 1.68 & -- & 54.18 & $65.5^{(c)}$ \\
\hline & Gold & $73,544^{(d)}$ & $16,397^{(\mathrm{e})}$ & $28,422^{(e)}$ & -- & $5,389^{(e)}$ & 123,752 \\
\hline & Silver(e) & 1,586 & & 477.5 & -- & 510.9 & 2574.4 \\
\hline 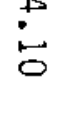 & $\begin{array}{l}\text { Uranium } \\
\text { Oxide }\end{array}$ & 532 & 117.5 & 448.4 & -- & 1097.9 & 2195.8 \\
\hline & $\begin{array}{l}\text { (a) Univer } \\
\text { (b) BCL ( } \\
\text { (c) Weight } \\
\text { (d) Derive } \\
\text { Mines } \\
\text { (e) Derive } \\
\text { (f) Averag }\end{array}$ & $\begin{array}{l}\text { ty of Utah } \\
5 \text { ). } \\
\text { average of } \\
\text { by author } f \\
81 \text { ) and } 197 \\
\text { from data } \\
\text { of values }\end{array}$ & $\begin{array}{l}(1980) \text {. } \\
\text { production methods. } \\
\text { rom energy and produ } \\
7 \text { Census of Minerals } \\
\text { BCL (1976). } \\
\text { BCL }(1975)\end{array}$ & $\begin{array}{l}\text { tion data in } 19 \\
\text { Industries (8ur }\end{array}$ & $\frac{\text { Minerals }}{\text { Iu of the }}$ & $\frac{\text { Yearbook }}{\text { ensus } 1981}$ & . Bureau o \\
\hline
\end{tabular}


TABLE 4.3. Energy Consumption in Metal Production (10 ${ }^{12}$ Btu), 1980

\begin{tabular}{|c|c|c|c|c|c|c|c|}
\hline & Production (st) ${ }^{(\mathrm{a})}$ & Mining & Grinding & Concentrating & Smelting & Refining & Total \\
\hline Copper & $1,054,000^{(b)}$ & 21.2 & 31.0 & 13.3 & 31.1 & 10.6 & 107.2 \\
\hline Lead & $604,432^{(c)}$ & 2.6 & 2.0 & 0.7 & 7.8 & 3.1 & 16.2 \\
\hline Zinc & $368,384(c)$ & 2.1 & 1.5 & 0.6 & $(g)$ & 20.0 & 24.2 \\
\hline Gold & $21.8^{(d)}$ & 1.6 & 0.4 & 0.6 & (h) & 0.1 & 2.7 \\
\hline Silver & $234.7^{(\mathrm{e})}$ & 0.4 & $(g)$ & 0.1 & (h) & 0.1 & 0.6 \\
\hline Uranium Oxide & $16,388^{(f)}$ & 8.7 & 1.9 & 7.3 & (h) & (h) & $17 . \underline{9}$ \\
\hline & & 36.6 & 36.8 & 22.6 & 38.9 & 33.9 & 168.8 \\
\hline
\end{tabular}

(a) In short tons. Source: U. S. Bureau of Mines (1980).

(b) This value represents $82 \%$ of production recovered by conventional techniques. Surface mines yield about $80 \%$ of conventionally recovered copper while underground mines yield $20 \%$ according to Minerals Yearbook 1980 (U.S. Bureau of Mines 1981).

(c) Domestic ores are predominantiy sulfide ores from underground mines according to BCL (1975).

(d) This value represents $67 \%$ of gold from precious metal ores Minerals Yearbook 1980. Approximately half of production is from underground mines and half from surface mines according to BCL (1976).

(e) This value represents the $22 \%$ of domestic production from silver ores. Most silver is from underground mines according to BCL (1976).

(f) This value represents the $46 \%$ of domestic production from underground mines, and the $29 \%$ of domestic production from surface mines according to Statistical Data on Uranium Industry (DOE 1981). Production estimated from Statistical Abstract of the United States National Data Book, Guide to Sources (Bureau of the Census 1982).

(g) Included in other activities.

(h) Not applicable. 
by microbial leaching are much greater than the production rates for precious metais. Microbial leaching therefore has the most significant energy-savings potential.

Both microbial and non-microbial heap leaching techniques begin by taking ore out of the ground and milling the rocks to reduce particle size. Instead of expensive beneficiation techniques, ore is transported to dump sites where aerators spray acidified water over the top surface. Since the organisms are ubiquitous, they proliferate with the introduction of the water. The metalladen solution accumulates in reservoirs at the foot of the piles. The metal is removed via solvent extraction and precipitation or other techniques.

A similar procedure is also used for in-situ leaching of uranium. Instead of mining, crushing, and grinding the ore, wells are drilled into mineralized zones and a solution containing oxidants is injected. Recovery wells pump the solution to the surface where the metal is removed from the leachate.

\subsubsection{Energy Savings from Biotechnology}

Based on methods currently used for copper production, the energy required for bacterially-assisted heap ieach methods exceeds the energy required for conventional processing. The following energy comparison dictates this conclusion: the heap leaching of copper requires at least $107.1 \times 10^{6}$ Btu/ton of copper. (a) The energy required for conventional processing is $101.7 \times 10^{6}$ Btu/ton of copper. A BCL (1976) study concluded that little can be done to change the current dump leaching process to save energy.

The in-situ leaching of copper from a deep-seated deposit appears to be the least energy-consuming biological recovery process. Approximately $80 \times$ $10^{6} \mathrm{Btu} / \mathrm{ton}$ copper is required even at $50 \%$ recovery. About $56 \times 10^{6}$ Btu/ton of

(a) Approximately $41 \times 10^{6}$ Btu/ton of copper is due to pumping of waste solution to the top of the dump. The other $46 \times 10^{6} \mathrm{Btu} / \mathrm{t}$ on of copper is the energy represented by the steel scrap consumed while precipitating copper from the leach liquor (BCL 1975). An additional $35 \times 10^{6}$ Btu/ton of copper is used in the subsequent refining process (University of Utan 1980). In addition, energy for mining is accounted for at $20.1 \times 10^{6}$ Btu/ton of copper. Since the low-grade ore is a byproduct of surface mining, the energy for mining is not usually included. 
copper is used in drilling, fracturing, and leaching. The remaining $24 \times$ $10^{6} \mathrm{Btu} / 1 \mathrm{~b}$ is used for electrowinning. Currently, energy requirements for in-situ leaching are about $20 \%$ lower than for conventional methods. If higher recoveries could be achieved, in-situ extraction would be even more attractive (University of Utah 1980).

Detailed energy consumption data for the heap and in-situ leaching of the other metals studied were not available; however, the conclusions drawn from copper recovery probably indicate an energy-savings potential of bacterial leaching of other metais. Therefore, it is assumed that all ores currently recovered by underground methods could be recovered by in-situ leaching methods using acid-producing or bioaccumulating bacteria. Using the data shown in Table 4.3, it is estimated about 0.11 quads are required to recover the copper, uranium, lead, and zinc metals by underground methods. Approximately 20\%, or 0.014 quads could be saved if bacterially-assisted in-situ methods were used.

\subsubsection{Research Needs for Metals Mining and Recovery}

In the future, deep deposit underground mining is expected to become more important as surface deposits are depleted. However, the geology or mineralogy of the underground deposits may not be suitable for in-situ leaching. In fact, studies have shown that considerable R\&D would be necessary to bacterially leach the uranium ores of the Rocky Mountains and south Texas because of their low pyrite concentrations (Brierley 1979). Thus, genetic engineering is necessary to increase effectiveness of bacterially-assisted in-situ leach methods.

The impact of bioaccumulation on the energy required for gold and silver mining is uncertain. Bioaccumulation techniques for recovery of gold and silver from dilute solutions could potentially increase the amount of goid and silver recovered in the United States. Since these solutions are waste streams, the energy currently required for mining, crushing, and grinding of gold and silver ores would not be necessary. Because of the high value of precious metals, however, the economics of recovery is not of as much concern as product quality and security. An optimistic evaluation is that the 0.002 quads currently required for mining, crushing, and grinding would be saved because gold and silver demand could be met more economically using bioaccumulation techniques. 
A very practical emphasis of bacterially-assisted leaching may be the mining of strategic minerals that are contained in ores that are of too low a grade to mine conventionally. The lower cost and specificity of biological recovery methods could decrease our reliance on foreign sources for these materials. Strategic minerals were not analyzed in this study because their recovery does not currently consume much energy.

\subsection{POLLUTION CONTROL}

An analysis by Serth and Hockett (1978) estimated that the U.S. consumed 1.7 quads of energy in 1977 for control of all pollutants. Their study estimated that in the future 2.5-3\% of total domestic energy demand will be required for control of pollution. Using a $3 \%$ estimate, in 1982 about 2.2 quads of energy were consumed and by the year 2000 an estimated 3.0 quads will be needed to control pollution.

There has been increased emphasis on environmental concerns, particularly in the areas of water quality, acid rain, and hazardous materials in the environment. It is expected that there will be changes to federal environmental regulations which will result in stricter standards for each of these areas. If stricter standards are enforced, the energy consumed by pollution control could exceed the $2.5-3 \%$ range estimated by Serth and Hockett.

Industry generates the major portion of this country's environmental pollution and also consumes the most energy for its control. Power generation and handling of municipal refuse are two other areas that consume appreciable amounts of energy for pollution control. Table 4.4 presents energy requirements for pollution control in these categories by pollutant type.

Natural biological systems have been available for many years to handle solid and liquid wastes, but as new biotechnological developments occur, it is possible that existing biological systems will be improved and that totally new pollution control methods will be created. The following sections discuss conventional methods for pollution control, potential energy impacts of biotechnology in this area, and future biological developments. 
TABLE 4.4. Pollution Control Energy by Consumer and by Pollutant Type

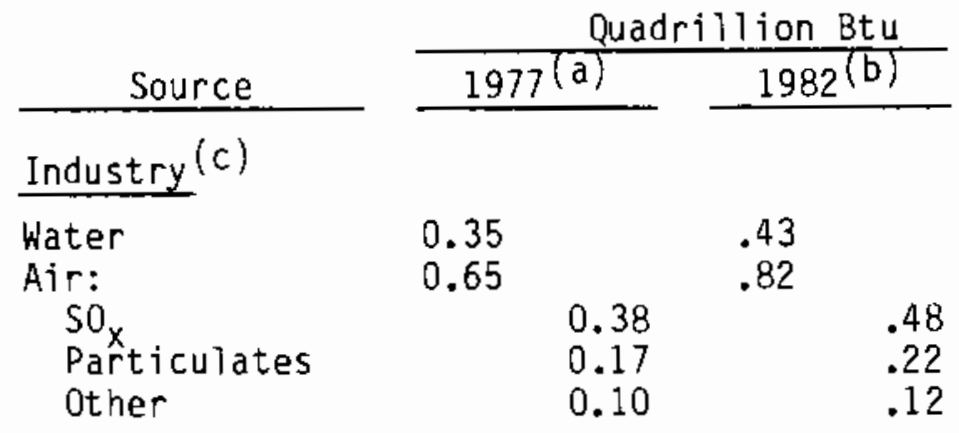

Power Generation

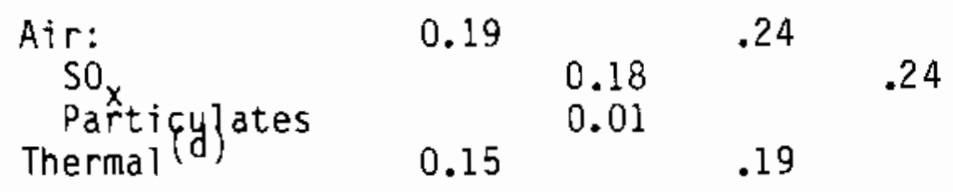

Municipal

\begin{tabular}{lll} 
Water & 0.27 & .35 \\
Solid waste & $\underline{0.10}$ & $\underline{.13}$ \\
\cline { 2 - 3 } & 1.71 & 2.16
\end{tabular}

\footnotetext{
(a) (Hockett 1978)

(b) Estimate based on $3 \%$ of total domestic energy demand of 72 quads.

(c) Industrial users as follows: Primary Metals (36\%); Chemicals (15\%); Paper $(9 \%)$; Petroleum (8\%); Fabricated Metals $(3 \%)$; Stone, Clay, Glass $(5 \%)$; Food $(7 \%)$; and all others $(18 \%)$; 1977.
(d) Thermal includes cooling water treatment.

\subsubsection{Possibilities for Biotechnological Poliution Control}

There are three types of pollutants that are of concern: those in the atmosphere, those in aqueous environments, and solid materials. This section discusses biological techniques for reducing a major atmospheric pollutant-- $\mathrm{SO}_{\mathrm{X}}$ from coal. Next, biological methods for treating industrial organic wastes, both aqueous and solid, are evaluated. Then the effects of large-scale usage of anaerobic digestion treatment for municipal waste water are estimated. 
Finally, calculations are provided for total energy savings if biological pollution control methods could be implemented.

\subsubsection{Control of $\mathrm{SO}_{\mathrm{x}}$ from Coal}

Most energy losses due to air pollution control are involved with $\mathrm{SO}_{\mathrm{x}}$ emissions. Since coal is the primary source of the $\mathrm{SO}_{\mathrm{x}}$ emissions, coal cleanup, including flue gas desulfurization, sulfur recovery, physical and chemical coal cleaning, coal gasification, and forced draft cooling towers, can be regarded as major air pollution control methods. Since industrial and power plant use of coal is expected to increase, control of $\mathrm{SO}_{\mathrm{x}}$ may become the largest single energy consumer in the future. If biotechnology is to make a significant impact on pollution control energy, methods for cleanup of coal must be developed.

Many different groups have studied the microbial removal of inorganic sulfur from coals (Brierley 1982; Andrews and Maczuga 1982; Beier 1982; Hoffman et al. 1981; Torma and Murr 1980; Detz and Barvinchak 1979). Inorganic suifur can be removed microbially with about $90 \%$ efficiency, giving sulfuric acid as a byproduct (Brierley 1982). The process is very time-consuming, requiring usually one to two weeks for complete removal (Andrews and Maczuga 1982; Hoffman et al. 1981; Torma and Murr 1980). For best remova1, the coal must be finely ground and the $\mathrm{pH}$ controlled at a highly acidic level. Additional heat is not needed.

A typical high sulfur coal might contain about $2 \%$ inorganic sulfur and $2 \%$ organic sulfur (Seward, Hollis, and Opalanko 1978), with the exact quantities varying depending on the coal source. Organic suifur is not removed under the conditions described in the preceding paragraph. When technologies are developed for removal of organic sulfur, the additional energy consumption is estimated to be fairly small; coal is already ground prior to burning, and little additional heat would be required.(a) Organic sulfur can currently be removed with about $20 \%$ efficiency if different bacteria are used and if the temperature

(a) Conversation with Dr. Minoo Dastoor, Jet Propulsion Laboratory. 
is maintained at $70^{\circ} \mathrm{C}$. (a) These studies have been at a bench scale only; there have been no large-scale determinations of economic feasibility or of energy consumption. $(a, b)$

\subsubsection{Control of Organic Aqueous and Solids Industrial Waste}

Aqueous organic wastes are typically concentrated and then either buried or incinerated, depending on the degree of hazard (Zaborsky 1983). Some waste streans can be treated with activated sludge (Siegrist 1981), which will degrade some organic compounds to acceptable discharge levels. Other types of microbial degradation are not widely used.

Microbes that will degrade specific chemical pollutants with high efficiency are being identified or genetically engineered (Siegrist 1981; Zaborsky 1983). There are organisms that can degrade long-lasting toxins, such as $2,4,5,-T$ (an herbicide) and dioxins (toxic byproducts of herbicides), as well as a host of other highly persistent phenolic compounds. Currently, many technical and economic considerations limit practical use of these microbes for control of specific pollutants (Zaborsky 1983).

In addition, innovative biodegradation techniques have been developed and tested for organic wastes from chemical plants and other sources (De Renzo 1980). These techniques use some variety of aerobic microbial degradation that reduces biological oxygen demand (BOD) by about $90 \%$, chemical oxygen demand (COD) by about $80 \%$, and total dissolved solids by about $20 \%$ to $50 \%$. These techniques include series lagoons for combining anaerobic with aerobic treatment, pure oxygen aeration for increased oxygen transfer and higher activated sludge concentrations, high-volume activated sludge treatment combined with fluidized bed combustion, and deep-shaft aeration to increase oxygen transfer with pressure. Energy calculations show that deep-shaft aeration would require the least energy per lb of BOD removed (Table 4.5).

(a) Conversation with Dr. Minoo Dastoor, Jet Propulsion Laboratory.

(b) Conversation with Dr. R. Attia, BCL. 
TABLE 4.5. Energy Requirements for Four Biodegradation Techniques

$\begin{array}{lc}\text { Technique } & \begin{array}{c}\text { Energy Required, } \\ \text { Btu/1b BOD Removed }\end{array} \\ \begin{array}{l}\text { Series lagoon } \\ \text { Washburn tunnel (high-volume } \\ \text { activated sludge) }\end{array} & 1.7 \times 10^{3(a)} \\ \begin{array}{l}\text { UNOX (pure oxygen aeration) } \\ \text { Deep-shaft aeration }\end{array} & 1.4 \times 10^{3(b)} \\ & 1.1 \times 10^{3(c)}\end{array}$

(a) Aeration power only, does not include pumping or raking energy.

(b) Mixing and $0_{2}$ generation power requirements only.

(c) Based on total power consumed.

\subsubsection{Treatment of Municipal Waste Water}

Anaerobic digestion is currently a net energy producer used extensively for treatment of sewage sludge. It generates a $50 \%$ to $60 \%$ methane gas (Kemmer 1979; EPA 1979) that can be burned to fuel other plant operations. Other types of waste have limited possibilities for treatment by anaerobic digestion, because fairly concentrated wastes are required, and because any sulfates are converted to sulfides, causing possible odor problems. Energy flows are well estabiished for digestion of sewage sludge (see Table 4.6). Energy input is primarily for heating the sludge, and approximately 4800 thousand Btu/ton of dry solids is generated, as surplus gas.

Anaerobic digestion is a proven technology, which could be more widely used for treatment of primary municipal waste water. One source estimated that if all municipal waste water were anaerobially digested, all of the electrical energy requirements for primary treatment plants could be supplied (Serth and Hockett 1978).

\subsubsection{Energy Savings Impact of Available Biotechnology}

Three potential methods were identified in the previous section for biotechnological pollution control: 1) removal of sulfur from coal to reduce $\mathrm{SO}_{\mathrm{x}}$ emissions into the atmosphere; 2) treatment of industrial organic wastes using 
TABLE 4.6. Energy Baiance for Anaerobic Digestion of Sewage Sludge

\begin{tabular}{|c|c|}
\hline Item & 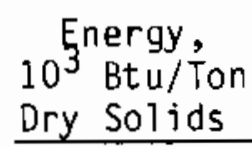 \\
\hline Raw sludge heating & 1300 \\
\hline Secondary sludge heating & 500 \\
\hline Mixing & 200 \\
\hline Total energy in & 2000 \\
\hline Gas produced & 4800 \\
\hline Total energy out & 2800 \\
\hline
\end{tabular}

Source: EPA 1979.

deep-shaft aeration; and 3) anaerobic digestion used more extensively to treat municipal waste water in addition to sewage sludge.

The energy used for $\mathrm{SO}_{x}$ removal necessitated by the burning of coal was estimated to be about .72 quads in 1982 . If all coal were microbially cleaned prior to use, about $45 \%$ of all the sulfur could be removed and energy required for $\mathrm{SO}_{\mathrm{x}}$ removal would be reduced. Assuming that microbial pretreatment would require about $20 \%$ of the energy for postcombustion cleanup, about .25 quads of energy could be saved (see Table 4.7). It should be emphasized that this energy savings estimate is hypothetical, since microbial desulfurization of coal is neither being done nor developed on a commercial scale.

TABLE 4.7. Potential Energy Savings for Microbial Desulfurization

\begin{tabular}{lcc} 
Item & Energy, Quad \\
\hline Energy for microbial treatment of coal, estimated & .07 \\
Energy for cleanup of nondegradable sulfur & & .40 \\
Total energy required if biotechnology used & .47 \\
Total energy currently used & .72 \\
Possible energy savings & .25
\end{tabular}


As mentioned previously, anaerobic digestion could be more widely used for treatment of primary municipal waste water. Based on the Serth and Hockett (1978) estimate that if all municipal waste water were anaerobially digested, all of the electrical energy requirements for primary treatment plants could be supplied; this would mean that about .26 quads per year of the .35 quads consumed for treatment of municipal waste water in 1982 (see Table 4.4) could be saved. This assumes that about .09 quads of power from sources other than electricity were also required.

If deep-shaft aeration were used to treat all industrial organic waste, about 0.20 quads of energy could be saved per year (see Table 4.8). Since deep-shaft aeration will not affect inorganic chemical concentrations, these were omitted from the energy savings estimate. The amount of energy that could be saved for the three combined pollution control methods discussed totals .71 quads, or $33 \%$ of the energy now estimated to be used for pollution control.

\subsubsection{Future Developments in Pollution Control}

In order to handle future environmental problems, research must be directed toward the development of economic, energy-efficient pollution control operations. Environmental groups, such as the Clean Air Coalition, are calling for reduced emissions of pollutants and stricter environmental regulations (Barton 1984). If stricter regulations are enacted, pollution control efforts should require larger energy inputs and become more costly. The Department of Defense predicts it will spend over one billion dollars in 1984 for cleaning up defense waste (Daley 1984), and pulp and paper companies are planning to spend more than 240 million dollars this year for environmental projects (Brusslan $1984)$.

Developments in the biotechnology area suggest that the biological behavior of microorganisms can be genetically manipulated to enhance characteristics that would aid pollution control efforts. Two emerging areas are enzyme degradation systems to handle hazardous organic chemicals, and systems utilizing metallothioneins to extract heavy metals from waste waters.

Enzymes are biochemicals, usually produced by microorganisms, which can be concentrated and purified. Once a microorganism is identified as having an 
TABLE 4.8. Series of Calculations to Determine Potential Energy Savings for Deep-Shaft Aeration of Organic Wastes

\begin{tabular}{|c|c|c|}
\hline Step & Item Being Calculated & Value of Item Being Calculated \\
\hline 1 & $\begin{array}{l}\text { Total energy requirement for deep-shaft aeration } \\
\text { (De Renzo 1980) }\end{array}$ & $1.1 \times 10^{3}$ gtu/l b BOD removed \\
\hline 2 & $\begin{array}{l}\text { Conversion of Step } 1 \text { value to energy/lb dry waste } \\
\text { a. BOD removed/day (De Renzo } 1980 \text { ) } \\
\text { b. Energy required per day to remove al } B O D \\
\text { c. Total dissolved sol ids per day (De Renzoj) (a) } \\
\text { d. Energy requlred per l b to aerate solids }\end{array}$ & $\begin{array}{l}1.9 \times 10^{3} \mathrm{Ib} \mathrm{BOD} / \mathrm{day} \\
1.3 \times 10^{3} \mathrm{Btu} / \mathrm{day} \\
2.8 \times 10^{2} \mathrm{Ib} 50 \mathrm{lids} / \mathrm{day} \\
9.5 \times 10^{\mathrm{B}+\mathrm{u} / \mathrm{Ib} \text { solids }}\end{array}$ \\
\hline 3 & $\begin{array}{l}\text { Total dry ( } 85 \text { ganic waste produced (De Renzo 1980) } \\
\text { in } 1982 \text { ) }\end{array}$ & $6.0 \times 10^{6}$ ton $/ y r$ \\
\hline 4 & $\begin{array}{l}\text { Total amount of energy to aerate all organic } \\
\text { wastes ( } S t e p 2 d \text { units converted and multipliad } \\
\text { by Step } 3 \text { ) }\end{array}$ & $1.1 \times 10^{13} \mathrm{Btu} / \mathrm{yr}$ \\
\hline 5 & Amount of energy used in 1982 for orgonle waste (d) & $2.1 \times 10^{14} \mathrm{Bt \omega} / \mathrm{yr}$ \\
\hline 6 & $\begin{array}{l}\text { Amount of energy savings with deep-shott aeration } \\
\text { (Step } 5 \text { mlnus Step } 4 \text { ) }\end{array}$ & $2.0 \times 10^{14} \mathrm{~B}+\mathrm{w} / \mathrm{Yr}$ \\
\hline
\end{tabular}

(a) Assumes that total dissolved solids = total chemlcal waste in the water.

(b) Estimated assumed equal to value report by De Renzo 1980.

(c) Since about $60 \%$ of the total chemical waste is organlc, we assumed that about half of the pollution control enerav would be used to process organle wastes.

(d) Assumes that total energy need for $B 00$ removal = total energy for dissolved solids treatment.

enzyme that can hydrolyze an organic pollutant, the enzyme structural genes could be transferred to a host organism capable of producing large volumes of the enzyme in industrial units. Using genetic engineering, researchers believe enzymes will become commercially available to provide an alternative to the currently available chemical, biological, or physical pollution control methods (Rogers 1984).

Metallothioneins are proteins, mainly found in higher organisms, which have a high affinity for various heavy metals (OTA 1984). It appears these proteins could be produced in large amounts by bacteria and immobilized on a solid support system. This system would then be used to extract the contaminant as the waste water passed over the immobilized protein. This process could be developed to decontaminate aqueous waste streams, particularly those from industry. 
Genetic engineering advances and improved bioreactors systems may result in pollution control methods that are superior to many of the methods currently in use. However, there are many biological and technological difficulties to overcome before new microbial systems can affect this area in a manner that will reduce energy consumption and be cost-effective.

\subsection{FOOD INDUSTRY}

The food industry consists of establishments primarily concerned with the manufacture and processing of food for human and animal consumption. Energy consumed by the food industry in 1982 has been estimated at 1.27 quads (U.S. DOE 1983). Of this, 0.66 quads of fossil fuel are used, of which natural gas is the major fuel and 0.5 quads of electricity. This industry is clearly fossil fuel-intensive, with natural gas as the major fuel form. Most of the fossil fuels purchased are used for process heat, with a small percentage used for space heating, refrigeration, and onsite electric power generation (Vitullio 1979).

According to the 1980 Annual Survey of Manufacturers (U.S. DOC 1982a), grain milling and sugar production were the top two energy users of purchased fueis and electricity in this industry. Table 4.9 presents the top five categories and the estimated energy consumed in 1980.

TABLE 4.9. Top Five Food Industry Energy-Consuming Groups in 1980

\begin{tabular}{|c|c|c|c|c|}
\hline & ndustry Group & $\begin{array}{c}\text { Electric Energy } \\
\text { (million kWh) } \\
\end{array}$ & $\begin{array}{l}\text { Fuels } \\
\text { (trillion Btu) } \\
\end{array}$ & $\begin{array}{c}\text { Total (a) } \\
\text { (trillion Btu) } \\
\end{array}$ \\
\hline 1. & Grain mill & 7118.6 & 131.2 & 154.6 \\
\hline 2. & Sugar & 2229.1 & 123.0 & 130.3 \\
\hline 3. & $\begin{array}{l}\text { Preserved fruits } \\
\text { and vegetables }\end{array}$ & 5992.4 & 106.1 & 124.8 \\
\hline 4. & Fats and oils & 3789.9 & 101.8 & 115.2 \\
\hline 5. & Meat & 7112.4 & 89.5 & 112.8 \\
\hline
\end{tabular}

(a) $10,400 \mathrm{Btu} / \mathrm{kWh}$ 
General energy-consuming activities that utilize heat include the following steps (Opila 1978):

1. dehydration by drying

2. concentration by evaporation

3. dewatering through centrifugation or filtration

4. thermal treatment by pasteurization or sterilization

5. hot water cleaning.

Washing and cooking represent the most intensive thermal-energy processes; refrigeration, although only a small energy user, is the most significant mechanical process (Palmer 1980).

\subsubsection{Potential Biotechnological Developments}

The application of biotechnology has potential for energy savings in the areas of food processing, cleaning/sanitation, and waste management.

Food Processing

Protein engineering will play an important role in the development of innovative, energy-efficient food processing methods. One such method uses enzymes to liquefy fruits and vegetables. Enzymatic processing methods have the potential to reduce energy requirements during production of juices, nectars, pulps, baby food, and possibly wines (Rohm 1983).

\section{Cleaning/Sanitation}

The development of low-temperature enzyme-based cleaning systems may play an important part in reducing the energy required for cleaning (Barror and Swientek 1981). The proposed cleaning systems combine enzyme activity (to break down protein-based soiling compounds) with surfactants that penetrate and suspend the soiling materials (Dellweg 1983).

\section{Waste Management}

Food processing generates large quantities of organic wastes that have an important biomass energy potential. As much as $25 \%$ of raw fruit input may end up as waste material in the juice processing industry (Davis and Kranzler 1981). In the dairy industry, 5 to 10 pounds of fluid dairy wastes (whey) are obtained for every pound of cheese produced (Goldstein 1981). 


\subsubsection{Potential Energy Savings from Biotechnology}

Biological organisms and their enzymes have been used commercially for many years in the production of bread, cheese, beer, wine, and other products. New developments in enzyme technology and genetic engineering have resulted in another biotechnological application--energy savings.

Two food processing industries that have a potential for energy savings through biotechnology are fruit and vegetable processing and meat packing. In 1980, approximately 5 billion pounds of juice was consumed in the United States (U.S. DDC 1982b). It has been estimated that juice pulping requires $7.3 \mathrm{Btu} / 1 \mathrm{~b}$ juice and heat treatment requires 83.3 Btu/lb juice (Brown and Hamel 1979). Up to $50 \%$ energy saving has been projected for these operations if enzyme liquefaction methods are used, ${ }^{(a)}$ or an energy saving of 0.23 trillion Btu. Besides juice production, other areas that could derive energy savings from enzymeliquification techniques are processing fruits and vegetables into pulps, nectars, and baby foods.

Fifteen percent of the fuel input to boilers in the meat packing industry is needed for hot water cleanup (Vitullio 1979). In 1980, 9-10 trillion Btu were used during hot water cleanup. Using enzyme-based cleaners, which require lower water temperatures, water temperatures coulo be reduced by $20^{\circ}$ to $30^{\circ} \mathrm{F}$, resulting in up to 0.38 trillion Btu of energy savings. Refrigeration energy requirements would be also reduced, since refrigerated rooms would not be heated as much during cleanup.

Cleaning and sanitation developments in the food industry could also save energy. Petrochemicals are a traditional feedstock for surfactants used in many food industry cleaning solutions. Replacing these with microbial biosurfactants would reduce the industry's petrochemical consumption. Energy savings estimates were not calculated, however.

Significant contributions to process heat requirements might be made by the waste generated by the food industry. Due to the seasonal nature of many

(a) Telecommunication from Rohm Tech, New York, January 20, 1984. 
of the food industries and the variety of residues, the energy savings potential of food wastes would have to be assessed at the plant level. Candidate energy recovery technologies that may be affected by biotechnological developments for food processing wastes include anaerobic digestion and fermentation.

\subsubsection{Research Needs for Foods Production}

The ability of biotechnology to support the energy conservation goals of the food industry will depend upon the direction of future research. This research should support those biological areas that have been identified as having potential energy-saving application in this industry. Particular attention should be paid to the development of enzymatic applications.

\subsection{AGR ICULTURE}

Modern farming relies heavily on machinery, agri-chemicals, and conditioning methods to cultivate the soil, produce crops, and raise livestock. In 1974 about 2.2 quads of energy were used by farmers, mainiy in the form of gasoline, diesel fuel, and natural gas (Table 4.10). The $1990 \mathrm{farm}$ energy demand is projected to be 2.4 quads. This $9 \%$ increase in energy demand is expected to result in a $20 \%$ increase in farm production for food and fiber, and in enough additional grain to produce 10 billion gallons of ethanol (Gavett 1980).

TABLE 4.10. Energy Use in Farm Production 1974-1990 (trillion Btu) (a) (Gavett 1980)

\begin{tabular}{|c|c|c|c|}
\hline Item & 1974 & $1980^{(b)}$ & 1990 (c) \\
\hline Fossil Fuels & 1188.2 & 1108.1 & 1143.9 \\
\hline Electricity $(d)$ & 332.8 & 289.3 & 349.3 \\
\hline Fertilizers & 621.2 & 649.2 & 822.9 \\
\hline Pesticides & 95.3 & 101.8 & 123.2 \\
\hline Total & 2237.5 & 2148.4 & 2439.3 \\
\hline
\end{tabular}

(a) Livestock (13\%); crops $(87 \%)$

(b) Estimated

(c) Projection

(d) Conversion to Btu: $1,000 \mathrm{kWh}=10.400 \times 10^{3} \mathrm{Btu}$ 
Ten billion gallons of ethanol has a liquid fuel value of about 800 trillion Btu. Diesel fuel is expected to be the dominant on-farm fuel, and natural gas is expected to contribute almost half the Btu in the form of fertilizers, pesticides, irrigation pumping, and crop drying (Gavett 1980).

\subsubsection{Energy Use for Conventional Methods}

Energy use in the food and fiber system is characterized by diversity and varying intensity depending on the region, crop, or process involved. Energy required to produce major feed grains is about 2,000 Btu/1b, compared with cotton, which requires $24,000 \mathrm{Btu} / 1 \mathrm{~b}$ (USDA 1980). Consumption can also vary with the region. In North Dakota corn production requires about $1,700 \mathrm{Btu} / 1 \mathrm{~b}$ and in New Mexico it requires $8,400 \mathrm{Btu} / 1 \mathrm{~b}$ (USDA 1980). Overall, it is est $i-$ mated that crop production accounts for about $89 \%$ of the energy used by the agricultural sector (Eakin 1981).

Manufactured agri-chemicals such as fertilizers (especially nitrogenous fertilizers) use large amounts of energy, with petrochemicals as the traditional feedstock. The use of these chemicals must be considered as an indirect energy input to agriculture.

Fertilizers, pesticides, and herbicides used to increase crop yields represent a large energy consumption and require an estimated $31 \%$ to $37 \%$ of the total energy input to crop production. Most of the energy used to manufacture these chemicals is due to the natural gas required to produce fertilizers. once manufactured, the energy needed to distribute the fertilizers has been estimated at 60 trillion Btu/yr (Vansuch 1979).

A typical pesticide spray at 1.12 lb active ingredient per acre is produced at an energy cost of $250 \times 10^{6} \mathrm{Btu} / \mathrm{lb}$ active ingredient per acre (Vansuch 1979). An accepted value of the energy used to manufacture herbicides is about 44,000 Btu/1b active ingredient (USDA 1980). This figure does not include the petroleum base used as a carrier for many herbicides.

At the farm level, fossil fuels are the major direct energy source; however, electricity is a major input for irrigated crops and dairy operations. Irrigation requires about $13 \%$ of the energy used in production agriculture. 
Tillage operations require 5.7 to 7.7 gallons of diesel fuel/acre tilled, or about $5 \%$ of the total industry energy consumption (USDA 1980).

Crop drying is an energy-intensive operation. To reduce moisture in corn by $10 \%$ from an acre yielding 125 bushels requires about 16 to 20 gallons of LP gas (USDA 1980). This energy consumption often exceeds the total needed for seed-bed preparation, planting, cultivation and harvesting (Vansuch 1979).

\subsubsection{Energy Savings Potential of Biotechnology}

Considerable energy savings could be realized in production agriculture if the genetic engineering of plants, bacteria, and algae continues to make progress. Energy-saving alternatives include genetic engineering to:

1) reduce the consumption of agri-chemicals and fuels, and 2) develop the growth of algal proteins for food.

The potential exists to use agricultural wastes for energy production through biomass conversion methods. Obstacles to deveioping agricultural wastes as a reliable source are encountered during collection, transportation, and storage of the material, and because of the seasonal nature of the industry. Biomass conversion technologies are discussed in the fuels and chemicals section.

\section{Reducing Consumption of Agri-chemicals and Fuels}

Conventional breeding programs may be combined with tissue-culture practices and recombinant DNA methods to allow screening for desired traits in single cells or plantlets in the laboratory. Progress is expected to be slow, however, because of the complex genetics of plants. For example, some plants (such as string beans) have ten times more DNA than human beings, and others have multiple pairs of chromosomes (Siwolop 1983). Some bacteria have a single gene that determines a specific trait, while plants often have many. Scientists believe that a plant's ability to fix nitrogen from the air is determined by a complex set of 17 genes (Siwolop 1983). The following is a list of biotechnological approaches that would reduce demand for agri-chemicals: 
- Fertilizers

1. Breed piants that assimilate fertilizer more efficiently, since it is estimated worldwide that only $50 \%$ of the applied nitrogen is absorbed by the plants, and only $3 \%$ of the phosphate. A $10 \%$ increase in efficiency is thought to be possible (Oelhaf 1978).

2. Transfer nitrogen-fixing genes from the bacterium Rhizobium to nonleguminous crops, such as corn and wheat, that cannot fix nitrogen. One paper reports that genetic engineers feel this will be possible in ten years (Siwolop 1983).

3. Develop microbial fertilizers by utilizing the nitrogen-fixing functions of certain bacteria and blue-green algae (Frankin 1983).

- Pesticides

1. Create varieties of crops that are disease- and pest-resistant.

2. Develop the insecticidal properties of bacteria, viruses, and funguses so that crop insect problems could be handled by microbially-produced insecticides.

- Herbicides

Use increased photosynthetic rates and/or improved breeding methods to develop varieties with better leaf coverage and faster earlier growth so that the plant will be established before the weeds grow.

Reducing the amount of agri-chemicals needed by agriculture should also reduce the direct fuel consumption of farm machinery used during distribution of chemicals. Fuel consumed during tillage operations could be reduced by the development and use of microbial or algal soil conditioners. Irrigation demands would be reduced through plant breeding of drought-resistant crops. In the case of corn, progress has been made in developing varieties with lower moisture content, which should reduce energy demarids for crop drying. For 
orchard crops, development of frost prevention techniques using bacterial virus sprays could replace a portion of the energy used in conventional frost protection methods (Genetic Tech. News 1983).

Through the use of advanced plant genetic techniques, a $10 \%$ reduction in both direct and indirect crop energy consumption appears possible. This would mean an energy savings of 170 to 195 trillion Btu/yr. Before any real savings can be achieved, however, the problems inherent in plant genetics must be overcome and public approval must be obtained for the release of geneticaliyengineered organisms to the environment.

Alternative Food Source

The algae Spirulina can be grown in mass cultures in large outdoor tanks or reservoirs and has the potential for making large volume, low-cost food proteins. Growing algae as a protein source appears to be less energy-intensive than many conventional protein sources. Table 4.11 compares energy requirements for farming the algae Spirulina with other protein sources. In

TABLE 4.11. Analysis of Spiruitina Algae and Other Protein Sources(a)

\begin{tabular}{|c|c|c|c|c|}
\hline & Product & $\begin{array}{l}\text { Percentage } \\
\text { Protein } \\
\end{array}$ & $\frac{\text { Energy Output }}{\text { Energy Input }}$ & $\begin{array}{c}\text { Land Area for } \\
\text { Year/Ton Product } \\
\text { Acres/Ton } \\
\end{array}$ \\
\hline 1. & Spirulina & 65.7 & 4.33 & 0.45 \\
\hline 2. & Soybeans & 34.0 & 1.18 & 1.19 \\
\hline 4. & Catfish & 17.6 & 0.10 & 3.95 \\
\hline 5. & Oats & 14.5 & 3.15 & 1.17 \\
\hline 6. & Beef $(c)$ & 13.6 & 0.38 & 71.52 \\
\hline 7 . & Eggs & 11.5 & 0.14 & 1.43 \\
\hline 8. & Corn & 9.0 & 3.02 & 0.44 \\
\hline 9. & Pork & 8.0 & 0.17 & 2.71 \\
\hline
\end{tabular}

\footnotetext{
(a) Adapted from Leesley (1980).

(b) In calculating energy inputs, solar energy input was not included, which allows vegetable sources to have ratios greater than one.

(c) Values averaged for range and feedlot beef.
} 
the table a ratio of total energy input to total energy output is presented. For the animal protein sources the ratio is much less than one, which indicates that they are energy inefficient. The vegetable protein sources are much more efficient. On the basis of energy efficiency, Spirulina is 3.67 times more efficient than soybeans (Leesley 1980).

In order for any energy savings to be realized from alternative food sources such as algae there must be an appreciable change in consumer demand, which currently favors the energy-intensive animal protein sources. 


\subsection{SUMMARY OF ENERGY SAVINGS FROH BIOTECHNOLOGY}

The use of biomass conversion technologies would result in a large savings of fossil feedstocks by the fuels and chemicals industry. In addition, the use of genetically engineered materials could also significantly reduce process fuel consumption for several industries.

\subsection{BIOMASS CONVERSION TECHNOLOGIES}

Biomass conversion deals with processes that produce renewable feedstocks and fuels from biomass to replace fossil-based materials. For biomass conversion, liquid or gaseous fuels production and utilization of biomass as a chemical feedstock were evaluated. The potential for energy savings is discussed below.

\subsubsection{Fuels Production}

The analysis performed in this study indicates that severa\} newer ethanol processes show net energy gains, assuming the byproducts are burned as fuel for the process. Synthesis gas and methanol from wood gasification also show net energy gains. Although net energy gain is useful for evaluating which fuels consume more energy in the conversion process than the product contains, it does not focus on the true advantage of biomass conversion processes: they convert low-value biological materials into desirable fuels.

Using wastes residues, surplus crops, and the technology currently available, about .3 quads of liquid fuels and 2.8 quads of gaseous fuels could be replaced by biomass-derived fuels. This represents $1 \%$ of the current liquid fuel consumption and 16\% of gaseous fuel consumption in the U.S. in 1983.

\subsubsection{Chemicals Production}

The development of a biomass-based chemical industry is practical based on biomass availability and a potential fossil feedstock savings of 2.1 quads. However, the process energy requirements could exceed conventional process fuel requirements by up to 1.15 quads due to problems such as diluted products. The development of energy-efficient bioprocess technologies is of critical importance to the technical and economic feasibility of a biomass-based chemical 
industry. In fact, the production costs must be sufficiently low so that even with new investments in plant and capital equipment, a biomass-based chemicals industry would be competitive with the already established fossil-based indusry.

\subsection{GENETIC ENGINEERING}

Genetic engineering facilitates the use of biologically-engineered enzymes and microorganisms to reduce process energy requirements. Applications evaluated for genetic engineering include fuels production, chemical feedstocks production, metals mining and recovery, pollution control, foods, and agriculture. The potential energy savings are discussed below.

\subsubsection{Fuels Production}

Based on PNL calculations, the 26.9 quads of liquid fuels consumed in 1982 could be replaced by 9.1 billion tons of wood for methanol production or 7.1 billion tons of corn for ethanol production. The 1982 demand for gaseous fuels could be supplied by 3.87 billion tons of wood for SNG production. At current yields, production of ethanol, methanol, and SNG in these quantities would require $792 \%, 253 \%$, and $108 \%$ of the estimated land available in the U.S. for the appropriate biomass feedstock.

Utilization of genetic engineering could realistically improve biomass feedstock yields to three times current levels. This would increase the feasibility of large-scale production of fuels from biomass feedstocks. It is unlikely, however, that the total liquid and gaseous fuel demand could be replaced using biomass, although there is the potential for partial substitution.

\subsubsection{Chemicais Production}

Bioprocessing methods to produce chemicals from biomass using microorganisms or enzymes have several potential advantages over conventional methods, but they currently consume more energy. Developments in biocatalyst and bioreactor design could minimize process energy requirements for both the conventional and biomass-based chemicals industry. With biomass feedstocks and low-energy bioprocesses, most of the fossil energy consumed by the industry 
could theoretically be saved, because the energy consumption of bio-derived chemicals would no longer be prohibitive. Genetic engineering will also save energy by stimulating the development of novel synthesis routes that directly convert low-value feedstocks such as biomass and coal into chemical endproducts.

\subsubsection{Metals Mining and Recovery}

Approximately $20 \%$ or 0.014 quads (in 1980) of the energy used for metal mining could be saved if bacterialiy-assisted in-situ recovery methods were utilized. Bioaccumulation techniques for the recovery of gold and silver from waste streams could potentially save most of the 0.002 quads (in 1980) required for mining of precious metals. Because of the high value of precious metals, product quality and security are important factors in addition to the economics of recovery.

\subsubsection{Pollution Control}

Use of microorganisms for pollution control could save at least 0.71 quads or $33 \%$ of the total energy (see Table 5.1). The three technologies discussed include microbial desulfurization of coal, anaerobic digestion of sewage, and deep-shaft aeration of industrial organic waste. Only anaerobic digestion is currently used commercially.

\begin{tabular}{|c|c|}
\hline Pollution Control Method & Energy Savings, Quads \\
\hline Microbial Desulfurization & 0.25 \\
\hline Anaerobic Digestion & 0.26 \\
\hline Deep-Shaft Aeration & 0.20 \\
\hline Total & 0.71 \\
\hline
\end{tabular}

\section{2 .5 Foods}

Existing biotechnological developments in the foods industry have a potential for energy savings in the areas of food processing, waste management, and cleaning/sanitation. Two food processing industries that have a potential for 
energy savings through biotechnology are fruit processing and meat packing. Approximately $50 \%$ of the energy required during the fruit maceration process, or 0.23 trillion Btu, could be saved using enzymatic liquefaction methods. Use of enzyme-based cleaners by the meat packing industry would save 0.38 trillion Btu. Process heat requirements could be reduced by burning wastes, and the use of microbial surfactants could replace surfactants from petrochemicals.

\subsubsection{Agriculture}

Considerabie energy savings could be realized in agriculture if genetic engineering of plant, bacteria, and algae continues to make progress. Reducing the consumption of agri-chemicals and fuels for growing and collecting crops would result from the development of disease- and pest-resistant plants. It is estimated that this development would save 0.17 to 0.20 quads per year. Lowcost algal food proteins could conserve much of the energy consumed by conventional protein production technologies; however, implementation is severely restricted by public acceptance. 


\section{REFERENCES}

ACR Company. 1980. Brochures: "The Small Fuel-Alcohol Distillery;" "Advantages of the ACR Process;" and "A General Description of the ACR Process for Producing Anhydrous Fuel Alcohol." ACR Company, Champaign, 11 inois.

Andren, R. K., M. Mandels, and J. Medeiros. May 1975. "Production of Sugars from Waste Cellulose by Enzymatic Hydrolysis." Paper presented at the 8th Cellulose Conference, Syracuse University, Syracuse, New York.

Andrews, G. F. and J. Maczuga. 1982. "Bacterial Coal Desulfurization." Paper presented at the Biotechnology and Bioengineering Symposium No. 12, May 11, 1982, Gatlinburg, Tennesee.

Barror, D. and R. J. Sweintek. 1981. "Low-Temp, Enzyme-based Cleaners Cut Labour and Energy Costs." Food Processing, February 1981, pp. 38-39.

Barton, K. 1984. "The Environmental Agenda for 1984." Environment. Vol. 26, No. 1, January/February 1984.

Bassham, J. A. 1977. "Increased Crop Production Through More Controlled Photosynthesis." Science, August 12, 1977.

Battelle Columbus Laboratories (BCL). 1975. Energy Use in Metallurgical and Nonmetallurgical Minerals Mining. PB-245759, BCL, Columbus, Ohio.

Battelle Columbus Laboratories $(B C L)$. 1976. Energy Use in Metallurgical and Nonmetallurgical Minerals Mining. PB-261150, $\overline{B C L}$, Columbus Ohio.

Beier, E. 1982. Gluekauf-Forschungshefte, 43(4):132-134.

Biomass Digest. June 1983. Vol. 5, No. 6 .

Brandt, E. F. 1983. "The 800 Ton per Day Country System for Processing and Gasifying Municipal Solid Waste." In Symposium Papers: Energy from Biomass and Wastes VII, pp. 473-494. Institute of Gas Technology, Chicago, Illinois.

Brierley, C. L. 1979. "Microbiology and Mining - Practices and Problems." In New Mexico Geology, Vol. 1, No. 3. New Mexico Bureau of Mines and Resources, Socorro, New Mexico.

Brierley, C. L. 1982. Sci.Am., Vol. 281, pp. 44-53.

Brown, H. L. and B. B. Hamel. 1979. Energy Anaiysis of 107 Industrial Processes. C00-2862-T1, Drexel University, Philadelphia, Pennsylvania.

Brusslan, C. 1984. "Will Stepped Up Enforcement Affect Paper Companies?" Paper Trade Journal. August 1984. 
Bureau of the Census. 1981. 1977 Census of Minerals Industries, Fuels, and Electricity Consumed. MIC77-SR-5, U.S. Government Printing Öfice, Washington, D.C.

Bureau of the Census. 1982. Statistical Abstract of the United States National Data Book and Guide to Sources, Edition 103. U.5. Government Printing office, Washington, D.C.

Bureau of the Census. 1982 Census of Minerals Industries Preliminary Report Industry Series. MIC82-I-10C(P), U.S. Government Printing Office, Washington, D.C.

Bureau of Mines. 1981. Minerals Yearbook 1980. Volume I, Metals and Mining. U.S. Government Printing Office, Washington, D.C.

Burwe11, C. C. 1978. "Solar Biomass Energy: An Overview of U.S. Potential" Science, Vol. 199, March 10, 1978, pp. 1041-1047.

Chambers, R. S., et a1. November 1979. Science, Vol. 206., pp. 789-795.

Chemical and Engineering News. "Top 50 Chemicals." June 11, 1984, p. 35.

D'Alessio, G. J. and R. P. Blaunstein. September 1980. "Alcohol Production from Agricultural and Forestry Residues." DOE-EV-0108, Argonne National Laboratories, Argonne, Illinois.

Daley, P. S. 1984. "Military Marches Toward New Horizons in Pollution Control." Pollution Engineering, February 1984.

David, M. L., et al. 1978. Gasahol Economic Feasibility Study. P063390, University of Nebraska, Omaha, Nebraska.

Davis, D. C. and G. A. Kranzler. 1981. "Energy Potential of Fruit Processing Residues." Paper presented at the 1981 American Society of Agricultural Engineers' Meeting, June 21-24, 1981, Orlando, Florida.

De Renzo, D. J. 1980. Biodegradation Techniques for Industrial Organic Wastes, Noyes Data Corp., Park Ridge, New Jersey.

Dellweg, H. 1983. Biotechnology Vol. 3. Verlag Chemie, Deerfield Beach, Florida.

Detz, C. M. and G. Barvinchak. 1979. "Microbial Desulfurization of Coal," presented at American Mining Congress Coal Convention, May 20, 1979, St. Louis, Missouri.

Donaldson, T. L. and 0. L. Culberson. 1983. An Assessment of the Potential for Production of Chemical Feedstocks from Renewable Resources. ORNL/TM-8432, Oak Ridge National Laboratory, Oak Ridge, Tennessee. 
Donovan, J. M., et a1. 1980. Physical and Chemical Characteristics of Synthetic Asphalt Produced from Liquefaction of Sewage Sludge. EPA Report R-806790-01, Pacific Northwest Laboratory, Richland, Washington.

Donovan, J. M., P. M. Molton, and T. F. Demmitt. October 1981. Fuel, $60(10): 898-903$.

Dunill, P., A. Wiseman, and N. Blakebrough, eds. 1980. Enzymic and NonEnzymic Catalysis. Nalstead Press, a division of John Wiley \& Sons, New York, NY.

Eakin, D., et al. 1981. An Analysis to Develop a Program for EnergyIntegrated Farm Systems. PNL-3981, Pacific Northwest Laboratory, Richl and, Washington.

Emert, G. H., et al. September 1980. Chemical Engineering Process, pp. 47-52.

Environmental Protection Agency (EPA). September 1979. Sludge Treatment and Disposal. EPA 6251/1-79-011, EPA, Washington, D.C.

Evans, A. R. 1980. "Tradeoffs of Energy Conservation and Environmental Quality." Paper presented at the Third World Energy Engineering Congress, October 15, 1980, Atlanta, Georgia.

Franklin, D. 1983. "Biotechnologists Build a Better Bug." Bioscience, November, 1983, pp. 678-679.

Gaines, L. L. and S. R. Shen. 1980. Energy and Materials Flow in the Production of 0lefins and Their Derivatives. ANL/CNSV-9, Argonne National Laboratory, Argonne, ITinois.

Gavett, E. E. 1980. "Overview of Energy Consumption in U.S. Agriculture -Past and Future." In Agricultural Energy: Selected Papers from 1980 ASAE Energy Symposium, pp. 20-24. American Society of Agricultural Engineers, St. Joseph, Michigan.

Genetic Technology News. 1983. "Bacterial Virus Will Fight Frost Damage." September 1983, pp. 2.

Goldstein, I. S. 1981. Organic Chemicals from Biomass. CRC Press, Baton Raton, Florida.

Haggin, J. and J. H. Krieger. 1983. "Biomass Becoming More Important in U.S. Energy Mix." Chemical and Engineering News, March 14, 1983, pp. 28-30.

Hoffmann, et a1. 1981. Applied and Environmental Microbiology, 42(2):259-271.

Holtberg, P. D., T. J. Woods, and R. H. Hiit. 1983. 1983 GRI Baseline Projection of US Energy Supply and Demand, 1982-2000. Gas Research Institute, Chicago, ITlinois. 
Kemmer, F. N. 1979. Nalco Water Handbook. McGraw-Hill Publishing Co., New York, New York.

Klass, D. L. 1983. "Energy from Biomass and Wastes: 1982 Update." Paper presented at Energy from Biomass and Wastes VII, January 23-24, 1983, Lake Buena Vista, Florida.

Leesley, M. E., et a1. 1980. "A Low Energy Method of Manufacturing High-Grade Protein Using Blue-Green Algae of the Genus Spirulina." In Agricultural Energy: Selected Papers from 1980 ASAE Energy Symposium, pp. 619-523, American Society of Agricultural Engineers, St. Joseph, Michigan.

Lewin, R. A. 1983. "Phycotechnology - How Microbial Genticists Might Help." BioScience, March 1983, pp. 177-179.

Levin, M., et al. 1983. Applied Genetic Engineering Future Trends and Problems. Noyes Publications, Park Ridge, New Jersey, U.S.A.

Lipinsky, E. S. "Foods from Biomass: Integration with Foods and Materials Systems." Science. Vol. 199. February 10, 1978, pp. 644-650.

Lipinsky, E. S. 1981. "Chemicais from Biomass: Petrochemical Substitution Options." Science, Vor. 212, June 26, 1981.

Little, Arthur 0., Inc. 1984. Study of Federal Biotechnology Policy Issues. National Science Foundation, washington, D.C.

Meyers, R. A., ed. 1983. Handbook of Energy Technology and Economics. John Wiley and Sons, Redondo Beach, California.

Milne, T. A. and M. N. Soltys. July 1981. Pyrolysis Mechanisms. SERI PR-6221347, Stanford Energy Research Institute, Stanford, California.

Molton, P. M. and T. F. Demmitt. August 1977. Reaction Mechanisms in Cellulose Pyrolysis: A Literature Review. BNbL-2297, Pacific Northwest Laboratory, Richland, Washington.

Mudge, L. K. et al. January 1981. Investigations on Catalyzed Steam Gasification of Biomass. PNL-3695, Pacific Northwest Laboratory, Richl and, Washington.

Mudge, L. K., et al. July 1983. Catalytic Gasification Studies in a Pressurized Fluid Bed Unit. PNL-4594, Pacific Northwest Laboratory, Richland Washington.

O'Brien, T. 1982. NBS and Industrial Biotechnology: Technical Developments and Future Measurements Needs. NBSIR 82-2549. National Bureau of Standards, Washington, D.C. 
Delhaf, R. C. 1978. Organic Agriculture: Economic and Ecological Comparisons With Conventional Methods. Atranheld, Osmun and Co., Montclair, New Jersey.

Office of Technology Assessment (OTA). 1983. "The Chemicals Industry." Industrial Energy Use, OTA, U.S. Government Printing Office, Washington, D.C.

Office of Technology Assessment (OTA). 1984. Commercial Biotechnology - An International Analysis. U.S. Government Printing Office, Washíngton, D.C.

Opila, R. L. 1978. "Energy for Food Processing." Chemtech. February 1978, pp. 104-107.

Palmer, W. B., et al. 1980. Cogeneration Technology Alternative Study. GE80 ET0104, General Electric, Schenectady, New York.

Palsson, B. 0., et a1. July 31, 1981. "Biomass as a Source of Chemical Feedstocks: An Economic Evaluation." Science. Vol. 213.

Paul, J. K., ed. 1980. Large and Small Scale Ethyl Alcohol Manufacturing Processes from Agricultural Raw Materials. Noyes Data Corporation, Park Ridge, New Jersey.

Pau1, J. K., ed. 1981. Genetic Engineering Applications for Industry. Noyes Data Corporation, Park Ridge, New Jersey.

Pimentel, D., et al. June 5, 1981. Science, Vol. 212.

Pober, K. and H. Bauer. March 1977. Chem. Tech., pp. 164-169.

Rogers, J. et a1. 1984. "Enzymatic Detoxification of Hazardous Organic Chemicals in the Environment." Paper presented at the American Institute of Chemical Engineers Summer National Meeting, August, 1984, Philadelphia, Pennsylvania.

Rohm Tech. 1983. "Juices Made from Whole Fruit: Great Tastes." Food Engineering, May 1983, pp. 66-67.

Sarbolouki, M. N. and J. Moacanin. 1980. Solar Energy, Vol. 25, pp. 303-315.

Science. "Solar Energy: Unsung Potential for Wind and Biomass." Vol. 200. May 12, 1979, p. 636.

Sealock, L. J., et al. July 1978. "Catalyzed Gasification of Biomass." Presented at the First World Conference on Future Sources of Organic Raw Materials, Toronto, Canada.

Serth, R. H. and R. S. Hockett. 1978. Energy Requirements for Pollution Control at Stationary Sources. EPA report C21304, PP. 449-458. Environmentai Protection Agency, Washington, D.C. 
Seward, W. H., J. R. Hollis, and R. S. Opalanko. 1978. A Survey of Environmental Control Technologies for Industrial Coal Use. ANL/ECT-8, Argonne National Laboratory, Argonne, IlTinois.

Shafizadeh, F. 1968. Adv. in Carbohydrate Chem., Vol. 23, pp. 419-474.

Sheppard, W. J., and B. Young. 1983. "Biomass - The Agricultural Perspective." In Biomass Utilization, Plenum Press, New York, New York.

Shen, S. Y. and A. F. Turnhollow. 1983. "Regional Impacts of Herbaceous and Woody Biomass Production on U.S. Agriculture." Paper presented at Energy from Biomass and Wastes VII, January 23-24, 1983. Lake Buena Vista, Florida.

Siegrist, T.W. 1981. J. of Water Pollution Control Federation, $53(6): 851-861$.

Siwolop, S. 1983. "Sowing the Seeds of Super Plants." Discover, December 1983, pp. 88-92.

Smith, R. D. and F. McCullough. 1980. Technical and Economic Feasibility of Ethanol Production in Washington State. RRC-80-R-667, PNRC-90-7-09-06, Rocket Research Company, Redmond, Washington.

Torma, A. E, and L. E. Murr. 1980. "Desulfurization of Coal by Microbial Leaching," EMD-2-67-3319, New Mexico Energy and Minerals Department, Santa Fe, New Mexico.

U.5. Department of Agriculture (USDA). 1980. Cutting Energy Costs - The 1980 Yearbook of Agriculture. Ed. J. Hayes. U.S. Government Printing Office, Washington, D.C.

U.S. Department of Commerce (DOC). 1982a. 1980 Annual Survey of Manufacturers. Bureau of the Census, Washington, D.C.

U.S. Department of Commerce (DOC). 1982b. 1982 U.S. Industrial 0utlook. Bureau of Industrial Economics, Washington, D.C.

U.S. Department of Energy (DOE). 1981. Statistical Data of the Uranium Industry. Report No. GJ0-100(81), U.S. Department of Energy, Grand Junction Area Office, Grand Junction, Colorado.

U.S. Department of Energy (DOE). 1983. Energy Conservation: Technology R\&D Program Plan. U.S. DOE, Washington, D. C.

University of Utah. 1980. An Assessment of Energy Requirements in Proven and New Copper Processes. D0E/CS/40132, University of Utah, Salt Lake City, Utah.

Vansuch, G. 1979. "Energy Use in Agriculture." In Industrial Energy Use Data Book, ORAU-160, Oak Ridge Associated Universities, Oak Ridge, Tennessee. 
Vitullio, M. 1979. "Food and Kindred Products." In Industrial Energy Use Data Book, ORAU-160, Oak Ridge Associated Universities, Oak Ridge, Tennessee.

Zaborsky, 0. R. Oetober 1983. Biotechnology, pp. 670-673. 
. 
APPENDIX A

PROCESS DETAILS OF LIQUID AND GASEOUS FUELS PRODUCTION 
APPENDIX A

PROCESS DETAILS DF LIQUID AND

GASEOUS FUELS PRODUCTIDN

This appendix contains some process details for the technologies briefly mentioned in Section 4.0 on the production of liquid and gaseous fuels. This information may be of interest if more detail is needed about any of these technologies.

\begin{tabular}{|c|c|}
\hline Technology & Purpose \\
\hline $\begin{array}{l}\text { Conventional Grain } \\
\text { Processing }\end{array}$ & $\begin{array}{l}\text { To produce beverage-quality } \\
\text { ethanol from arain }\end{array}$ \\
\hline
\end{tabular}

Katzen Grain

Processing

Chemapec Grain

Processers

\begin{abstract}
To prond
\end{abstract}
To produce a fuel-grade alcohol from grain

To produce a fuel-grade alcohol from graln

To produce ethanol by acid hydrolysis of agricultural residues

\author{
Procedure \\ 1) Graln is ground, heated with dilute \\ aqueous acio. 2) Glucose from (1) \\ fermented to ethanol. 3) Distillation to \\ $50 \%$ ethanol, removal of solids. 4) Drying \\ of sollds to produce DDG. 5) Distillate \\ from (3) concentrated to 958 ethanol. \\ 6) Remaining water removed from alcohol \\ with benzene distillation. \\ 1) Saccharification and fermentation \\ procedures simllar to conventional. 2) \\ All distillation steps are combined. \\ 3) Gasoline used to remove alcohol as well \\ es to dewater $i t$, saving processing \\ energy. \\ 1) Saccharification and fermentation \\ procedures simliar to conventional. \\ 2) All distillation steps are comblned. \\ 3) Heat recycled to dry the DDG. \\ 1) Separation of starch from graln \\ residues before fermentation is begun. \\ 2) Continuous vacuum evaporation of \\ alcohol durlng fermentation. 3) Methane \\ production from waste streams, fuel used \\ for plant bollers. \\ 1) Residue ground, digested with dilute \\ acid to remove hemicellulose. 2) Strono \\ acid digestion to dissolve cel lulose. \\ Lignin filtered out. 3) Methanol added to \\ acid solution from (2) to precipitate
}




Technology

Conventional Acid

(contd)

Ac1d Hydrolysis of wood

Natick Process

Wilke Process

Gulf Process

Paciflc Northwest Laboratory wood Gasification
Procedure

cellulose. 4) Celtulose from (3) acidhydrolyzed to glucose. 5) Glucose fermented to ethanol. 6) Distillation and drying steps for ethonol similar to those in conventional grain processina.

1) Very similer to procedure for acid hydrolysis of agrleultural residues. More collection, transportation energy required.

Enzymatic hydrolysis of celluloslc wastes

1) Celiuiosic material finely ground. 2) Cellulose degraded with enzyme derived from fungus Trichoderma viride to form qlucose. 3) Glucose fermented to ethanol. 4) Ethanol stream concentrated, distifled, drled as before, but more energy required for the more dilute product streams.

Enzynatic hydrolysis of cellulosic wastes

1) After grinding, cellulosic wastes partially hydrolyzed with dilute acid. 2) Cellulose degraded with protease peptone. 3) Glucose streams fermented to ethanol. 4l Process streans concentrated and distliled as in the Notlck process.

Enzymatlc hydrolysis of cellulosic wastes

To produce low-to-medium Btu aas or methanol from rood
1) Celiulosic wastes finely ground.

2) Saccharification and fermentation steps are simultaneous, and on a continuous basis. 3) Enzyme production is continuous. Steps (2) and (3) reduce the volume of the product streams, and the ethanal distilletion energy required.

1) Collection and chipping of biomess. 2) Reaction of steam with wood or bicmass chlps in a fluidized bed gasifier at $750 \mathrm{C}$. 3) Catalyst selection determinas tinal product composition. 4) Shltt conversion to control desired hydrogen/carbon monoxide ratio. 5) Removal of acid gas and sulfur traces, 6) if methanol is produced, final catalytic resction between hydrogen and carbon monoxide. 
Pyrolysis

Liquefaction
Purpose

To produce an olly liquid fuel from biomass

To produce an olly liquid fuet from blamass
Procedure

1) Collection, grinding, and drying of biomass, 2) Reaction of biamass at temperatures between 400-700 C, wth inert atmosphere, reduced pressure, short residence time, 3) Separation of liquid products from char. 4) Further treating of liquid products to reduce oxygen content.

1) Collectlon and grinding of biomess. 2) Reaction of wet bicmass at 300-350 C, 1500-2500 psi, sodi un carbonate catalyst, retention times $15 \mathrm{mln}-1 \mathrm{hr}$.

3) Separation of Ilquid product from char. 4) Further treatlng of Ilquid products. 
APPENDIX B

BIOMASS PRODUCTION REQUIREMENTS FOR LIQUID AND GASEOUS FUEL 
APPENDIX B

\section{BIOMASS PRODUCTION REQUIREMENTS FOR LIQUID AND GASEOUS FUEL}

\section{B.1 ETHANOL PROOUCTION REQUIREMENTS}

1. The production of one quad of ethanol from corn by the Chemapec process requires about $1.29 \times 10^{8}$ tons of grain.

2. An additional $8.55 \times 10^{6}$ Btu/ton of corn feedstock would be required for manufacturing of fuel for growth, fertilization, collection, and processing. About $4.65 \times 10^{6} \mathrm{Btu} /$ ton of the energy required for these activities could be met by burning the DDG by-product as fuel. Therefore, the actual energy required is $3.90 \times 10^{6} \mathrm{Btu} / \mathrm{ton}$ biomass, which is assumed to be liquid fuel to drive vehicles.

3. Based on a net value of $3.9 \times 10^{6}$ Btu/ton of biomass from Step 2, an additional 0.51 quads of ethanol must be manufactured to produce 1 quad of ethanol to replace liquid fossil fuels (Step 2 times Step 1).

4. The manufacture of an additional 0.51 quads of ethanol to produce 1 quad of ethanol to replace liquid fossil fuels will require 0.26 quads of ethanol, etc., etc.

5. The amount of ethanol that must actualiy be produced to obtain 1 quad of ethanol is approximated by the series

$$
\sum_{n=0}^{\infty} 0.51^{n}=S_{n}
$$

6. $\sum_{n=0}^{\infty} 0.51^{n}$ quads $=2.04$ quads 


\section{B.2 METHANOL PRODUCTION REQUIREMENTS}

1. The production of one quad of methanol by gasification of wood requires about $2.03 \times 10^{8}$ tons of wood biomass (Mudge et al. 1980).

2. An additional $.59 \times 10^{6} \mathrm{Btu} /$ ton of wood is required for manufacture of fuel to cultivate, (a) fertilize, harvest, collect, and transport the short-rotation wood biomass feedstocks (Meyers 1983). This includes the energy cost of the ammonia fertilizer. Processing to methanol requires an additional $1.40 \times 10^{6} \mathrm{Btu} /$ ton of wood.

3. Based on a value of $1.99 \times 10^{6} \mathrm{Btu} /$ ton of wood from Step 2, an additional .40 quads of renewable fuel must be manufactured to replace 1 quad of nonrenewable fuel (Step 2 times Step 1 ).

4. The production of .40 quads of methanol to manufacture 1 quad of methanol would require .16 quads of methanol etc. etc.

5. The amount of methanol that must actually be produced to supply a11 the energy requirements of 1 quad of fossil fuel substitute is approximated by the series

$$
\sum_{n=0}^{\infty} \cdot 40^{n}=S_{n}
$$

6. $\quad \sum_{n=0}^{\infty} \cdot 40^{n}=1.67$

\section{B.3 SNG PRODUCTION REQUIREMENTS}

1. Based on a feasibility study that investigates steam gasification of biomass, the production of 1 quad of methane requires $1.92 \times 10^{8}$ tons of wood biomass feedstock (Mudge 1983).

2. An additional $.86 \times 10^{6} \mathrm{Btu} /$ ton of wood is required for manufacture of fuel to cultivate, fertilize, harvest, collect, transport, and process the short-rotation wood biomass (Meyers 1983, Mudge 1983).

(a) Assumes .07 Btu energy inputs required/Btu of wood output. 
We assume $.47 \times 10^{6} \mathrm{Btu} /$ ton of wood can be obtained from the byproduct char. Therefore . $39 \times 10^{6} \mathrm{Btu} /$ ton of wood must be obtained from a liquid fuel such as methanol.

3. To produce $.39 \times 10^{6} \mathrm{Btu} /$ ton of wood or .07 quads of methanol actually requires the production of .12 quads of methanol (Section B.2, step 6 times .07 quads).

4. The production of .12 quads of methanol requires the growth of $.24 \times$ $10^{8}$ tons of wood biomass (see Section B.2, step 1 ).

5. The total amount of wood biomass that must be grown to provide 1 quad of $S N G$ is $2.16 \times 10^{B}$ tons (step 1 plus step 4 ). 



\section{DISTRIBUTION}

No. of

Copies

OFFSITE

6 M. E, Gunn

CE-142

U.S. Department of Energy

1000 Independence Avenue

Washington, DC 20585

6 J. J. Eberhardt

CE -142

U.S. Department of Energy 1000 Independence Avenue washington, DC 20585

6 T. Levinson

CE-142

U.S. Department of Energy 1000 Independence Avenue washington, DC 20585

27 DOE Technical Information Center

R. B. Abarcar

Energetics, Inc.

9210 Route 108

Columbia, MD 21045

T. T. Bramlette

Sandia Laboratories

P.0. Box 969

Livermore, CA 94550

J. A. Carpenter, Jr.

Oak Ridge National Laboratory

Bidg. 4508 Room 263

P.0. Box $X$

Dak Ridge, TN 37831

M. Clayton

Jet Propulsion Laboratory

4800 Oak Grove Drive

Mail Code 125-159

Pasadena, CA 91109
No. of

Copies

M. Dastoor

Jet Propulsion Laboratory

4800 Oak Grove Drive

Mail Code 122-123

Pasadena, CA 91109

T. M. Dyer

Sandia Laboratories

P.0. Box 969

Livermore, CA 94550

C. Fink

Energetics, inc.

9210 Route 108

Columbia, MD 21045

R. E. Holtz

Argonne National Laboratory

9700 South Cass Avenue

Building 330

Argonne, IL 60439

S. Hsu

National Bureau of Standards

Bidg. 220 Room A-215

Washington, DC 20234

M. Kaminsky

Argonne National Laboratory

9700 South Cass Avenue

Argonne, IL 60439

K. G. Kreider

National Bureau of Standards

Physics Bldg. B-50

Washington, DC 20234

R. Phen

Jet Propulsion Laboratory

4800 Oak Grove Drive

Pasadena, CA 91109 
No. of

Copies

C. W. Robinson

Sandia Laboratories

P.0. Box 969

Livermore, CA 94550

A. Schaffhauser

Oak Ridge National Laboratory

Bldg. 4508 Maiicode 110

P.0. Box $X$

Oak Ridge, TN 37830

K. Smith

Albuquerque Operations office

P.0. Box 5400

Albequerque, NM 87185

W. H. Thielbahr

Idaho Operations office

550 Second Street

Idaho Falls, I0 83401
ONSITE

OOE Richland Operations Office

H. E. Ransom/0. R. Segna

53 Pacific Northwest Laboratory

W. B. Ashton

D. L. Brenchley (20)

A. D. Chockie

E. A. Griffin (5)

R. A. Hutchinson

C. H. Imhoff

D. R. Johnson

D. C. Kuick

J. A. Russell (5)

J. K. Young (10)

Publishing Coordination MH (2)

Technical Information (5) 